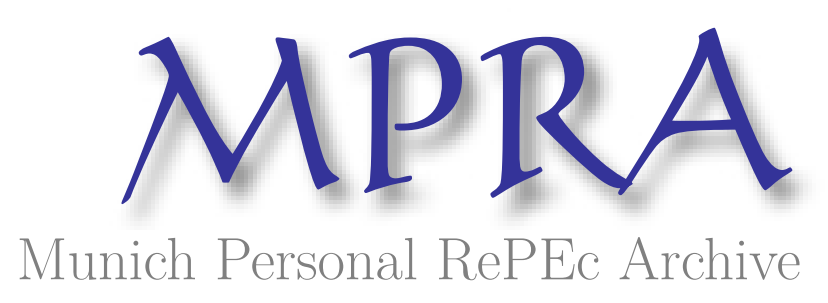

\title{
From transition to market: Evidence and growth prospects
}

Fischer, Stanley and Sahay, Ratna and Vegh, Carlos

International Monetary Fund

April 1998

Online at https://mpra.ub.uni-muenchen.de/20615/

MPRA Paper No. 20615, posted 11 Feb 2010 02:04 UTC 


\section{IMF Working Paper}

(C) 1998 International Monetary Fund
This is a Working Paper and the author(s) would welcome any comments on the present text. Citations should refer to a Working Paper of the International Monetary Fund. The views expressed are those of the author(s) and do not necessarily represent those of the Fund.

WP/98/52

INTERNATIONAL MONETARY FUND

\title{
From Transition to Market: Evidence and Growth Prospects
}

Prepared by Stanley Fischer, Ratna Sahay, and Carlos A.Végh ${ }^{1}$

April 1998

\begin{abstract}
This paper presents evidence on the behavior of output and inflation in the transition economies during 1992-95. A regression analysis explores the differences in output performance across the transition economies during this period. The paper then engages in a numerical, somewhat speculative, exercise to assess the long-run growth potential of the transition economies. It concludes that it should take about 20 years for the faster reformers to reach current OECD per capita levels.
\end{abstract}

JEL Classification Numbers: F41, F43, P20

Keywords: transition, growth

Author's E-Mail Address: sfischer@imf.org; rsahay@imf.org; cvegh@ucla.edu

${ }^{1}$ Stanley Fischer is First Deputy Managing Director at the IMF; Ratna Sahay is Deputy Division Chief in the Research Department; and Carlos Végh, currently an Associate Professor at UCLA, was a Senior Economist in the Research Department when this paper was written. This paper was prepared for an OECD volume on Lessons from the Economic Transition: Central and Eastern Europe in the 1990s and presented at the OECD colloquium on "Economic Transformation and Development of Central and Eastern Europe: What Lessons from the 1990s?," held in Paris on May 29-30, 1996. We thank Sergey Alexashenko, Gérard Bélanger, David Bendor, Scott Brown, Carlo Cottarelli, Laszlo Csaba, Stanislaw Gomulka, Jim Haley, Balazs Horvath, Alfred Kammer, Russell Kincaid, Silvana Malle, Hunter Monroe, John Odling-Smee, Mohammad Shadman-Valavi, Nicholas Stern, Nancy Wagner, Georg Winckler, Jeromin Zettelmeyer, and conference participants for helpful comments and discussions; our IMF colleagues for making data available and helping us interpret them; Manzoor Gill for excellent research assistance; and Catherine Fleck for excellent editorial assistance. 
CONTENTS

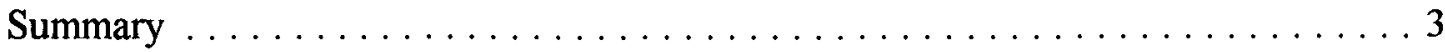

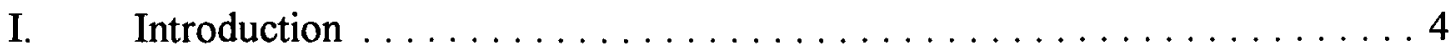

II. Recent Experience in the Transition Economies $\ldots \ldots \ldots \ldots \ldots \ldots$

A. Basic Macroeconomic Indicators . . . . . . . . . . . . . . . . 5

B. Stabilization and Growth . . . . . . . . . . . . . . . . 13

III. Determinants of Growth and Inflation in the Transition . . . . . . . . . . . 19

IV. Growth Prospects in the Long-Run . . . . . . . . . . . . . . . . . . 24

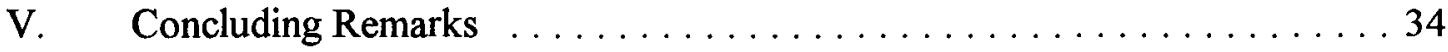

Tables:

1. Annual Output Growth in Transition Economies, 1989-95 . . . . . . . . 6

2. Annual Inflation in Transition Economies, $1989-95 \ldots \ldots \ldots \ldots \ldots \ldots$

3. Inflation and Output Performance in Transition Economies, 1989-95 . . . 8

4. Stabilization Programs in Transition Economies, 1989-95 . . . . . . . . . . 14

5. Fixed Effects Model for 25 Transition Economies, 1992-95 . . . . . . . 23

6. Factors Affecting Long-Term Growth in Transition Economies . . . . . . 25

7. Selected Transition Economies in a Global Perspective . . . . . . . . . . . . . 29

8. Selected Transition Economies: Forecasting Long-Term Trend Growth (Barro) . . . . . . . . . . . . . . . . . . . . . . . . . 30

9. Selected Transition Economies: Forecasting Long-Term Trend Growth

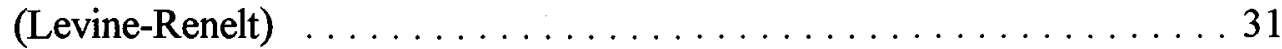

10. Selected Transition Economies: Forecasting GDP Convergence to

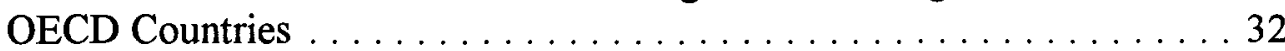

Figures:

1. Real GDP Growth Profiles in Calendar Time $\ldots \ldots \ldots \ldots \ldots \ldots \ldots$

2. Real GDP Index Profiles in Calendar Time $(1989=100) \ldots \ldots \ldots \ldots 11$

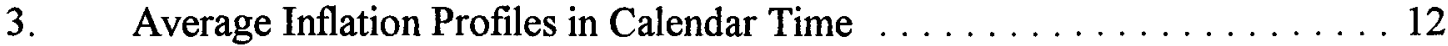

4. Real GDP Growth Profiles in Stabilization Time . . . . . . . . . . . . 16

5. Real GDP Index Profiles in Stabilization Time $\ldots \ldots \ldots \ldots \ldots \ldots \ldots$

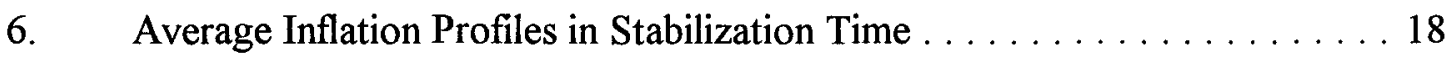

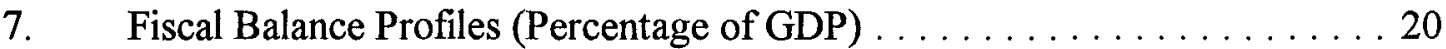

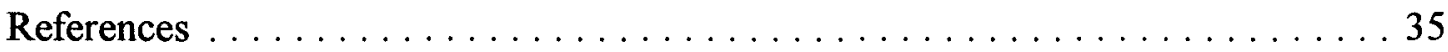




\section{Summary}

A priori speculation in the early 1990 s about the nature of the economic transition in the formerly-planned economies can now give way to a discussion of what has happened so far, and to a better-informed speculation of what may happen in the future. So far, the leading reformers of Central and Eastern Europe have moved impressively down the road to a market economy, and most others have taken major strides toward stabilization and reform. The output declines have stopped in all countries that have stabilized, with growth resuming in most of them. The fear that political considerations would hinder reform unless progress was rapid has turned out not to be valid in most countries.

This paper looks at the economic progress made so far by the transition economies, and evaluates their long-run prospects for growth. The paper first presents data that summarize the behavior of output and inflation in the transition economies, and then regression evidence that seeks to account for differences in performance among countries.

The paper then turns to a numerical, but more speculative, exercise to assess the long-run growth potential of the transition economies. Based on estimates presented in past crosscountry studies, we predict growth rates for the transition economies, which depend on initial conditions and such control variables as investment ratios and government consumption, which reflect government policies. Given the uneven progress in structural reforms, benefits from both well-directed government spending on reforms and foreign direct investment in enhancing human and physical capital are potentially large. Although admittedly crude, projections based on standard growth regressions suggest that it will take about 20 years for the faster reformers to reach current OECD per capita income levels. 


\section{INTRODUCTION}

It is now over six years since the start of the Polish economic reform program, and over four years since the breakup of the Soviet Union. A priori speculation about the nature of the economic transition can now give way to a discussion of what has happened so far, and to a better informed speculation - though speculation nonetheless-of what may happen in future. The story so far is that the leading reformers of Central and Eastern Europe (CEE) have moved impressively down the road to macroeconomic stability and a market economy, and that most of the remaining countries have taken major strides towards stabilization and reform. The output costs of reform in most economies have probably exceeded expectations, ${ }^{2}$ but output declines have stopped in all countries that have stabilized and growth has begun in most of them. The fear that politics would not sustain reform unless progress was rapid has turned out not to be valid in most countries. ${ }^{3}$

In this paper, we take a look at the progress made so far by the transition economies in their journey towards a market economy, and evaluate their long-run prospects for growth.

Specifically, the paper first presents data that summarize the behavior of output and inflation in the transition economies, and then regression evidence that seeks to account for differences in performance among countries. The regressions, which cover the period 1992-95, update results based on data through 1994 presented in Fischer, Sahay and Végh (1996a). ${ }^{4}$ We then turn to a numerical, but more speculative, exercise to assess the long-run growth potential of the transition economies.

\section{RECENT EXPERIENCE IN THE TRANSITION ECONOMIES}

In this section we examine the behavior of GDP growth and inflation for 26 economies in transition in eastern Europe, the former Soviet Union, and Mongolia. Most of the data used in this paper have been provided by IMF economists working on these countries. ${ }^{5}$ It is well known that these data are likely to suffer from serious biases. In particular, the output data are subject to both conceptual and measurement problems. At a conceptual level, prices before the transition were out of line with both costs and world prices, and goods were in any case

${ }^{2}$ We believe this to be true even taking account of data imperfections that generally overstate the decline of output.

${ }^{3}$ Aslund, Boone, and Johnson (1996) make a convincing case that reformers have done well at the polls.

${ }^{4}$ To the extent possible, we will make the presentation self-contained, referring to previous results in footnotes.

${ }^{5}$ See Fischer, Sahay, and Végh (1996a) for details on data definitions, sources, and limitations. 
often not available at those prices. As relative prices change in the transition process and resources move towards sectors whose prices have risen, output declines in base prices are overstated relative to declines measured at world or new prices. The measurement problems are mostly related to the fact that as state sector output declines and private sector output rises, an increasing share of output tends not to be recorded given that statistical services-some of which had to be built essentially from scratch-are still rudimentary.

\section{A. Basic Macroeconomic Indicators}

Tables 1-3 show annual output and inflation data for the 26 transition economies since $1989 .^{6}$ Several facts stand out:

- Output declines during the transition have been very large. Table 1 presents annual output growth data for the 26 countries in our sample for the period 1989-95. As of 1995 , the reported average cumulative output decline during the transition process was 41 percent (Table 3 ). In several countries, reported output has fallen by around two-thirds, which would indicate a virtual collapse of the economy. While these data are surely exaggerated, output declines have nonetheless been dramatic. ${ }^{7}$ The output decline was most severe in the former Soviet Union countries dependent on intrarepublican trade and in those that suffered civil war or trade embargoes-Armenia, Georgia, Azerbaijan, Moldova, Tajikistan and Ukraine in the FSU, and Croatia and Former Yugoslavian Republic of Macedonia (FYRM) in CEE (Table 3). To gain some perspective, recall that output in the United States declined by 34 percent during the Great Depression. Even though there were surely better reform strategies than those actually pursued, the creative destruction of the transition process would have implied large output declines even under the best policies. ${ }^{8}$

- The worst is over in most economies: as of 1995, 14 out of the 26 economies in our sample had begun to grow. Growth began as early as 1993-94 in most CEE and the Baltics, but by 1995 was not yet apparent in the official data for two-thirds of the FSU countries.

${ }^{6}$ Data for China and the Indochinese economies in transition are not included in this study.

${ }^{7}$ Kaufmann and Kaliberda (1995) construct estimates of output that draw, among other variables, on electricity consumption. They conclude that the overall GDP decline during 1989-94 was 17 percent in CEE and 33.4 percent in the former Soviet Union.

${ }^{8}$ Sachs (1996) makes the case that a substantial and coordinated aid effort in 1992 would have made the Russian reform process much more successful. 
Table 1. Annual Output Growth in Transition Economies, 1989-95

\begin{tabular}{|c|c|c|c|c|c|c|c|}
\hline Country & 1989 & 1990 & 1991 & 1992 & 1993 & 1994 & 1995 \\
\hline Albania & 9.8 & -10.0 & -28.0 & -7.2 & 9.6 & 9.4 & 8.6 \\
\hline Armenia & 14.2 & -7.2 & -11.8 & -52.3 & -14.8 & 5.3 & 5.0 \\
\hline Azerbaijan & -4.4 & -11.7 & -0.7 & -22.1 & -23.1 & -21.1 & -13.2 \\
\hline Belarus & 7.9 & -3.2 & -1.2 & -9.6 & -10.7 & -19.1 & -10.2 \\
\hline Bulgaria & -0.5 & -9.1 & -11.7 & -7.3 & -2.4 & 1.4 & 2.5 \\
\hline Croatia & -1.5 & -8.5 & -20.9 & -9.7 & -3.7 & 0.8 & -1.5 \\
\hline Czech Republic & 1.4 & -1.2 & -14.2 & -6.4 & -0.9 & 2.6 & 4.8 \\
\hline Estonia & -1.1 & -3.6 & -11.9 & -21.6 & -8.4 & 3.0 & 4.0 \\
\hline Georgia & -4.8 & -12.4 & -20.6 & -44.8 & -25.4 & -11.3 & -5.0 \\
\hline Hungary & 0.7 & -3.5 & -11.9 & -3.0 & -0.8 & 2.9 & 1.7 \\
\hline Kazakhstan & -0.4 & -0.4 & -18.8 & -13.9 & -12.0 & -25.0 & -8.9 \\
\hline Kyrgyz Republic & 3.0 & 4.0 & -5.0 & -19.3 & -16.1 & -26.2 & 1.3 \\
\hline Latvia & 3.0 & -2.3 & -11.1 & -35.2 & -14.8 & 2.0 & 0.4 \\
\hline Lithuania & 1.5 & -5.0 & -13.4 & 0.0 & -18.4 & 1.0 & 3.5 \\
\hline Macedonia, FYR & 0.9 & -9.7 & -10.7 & -21.1 & -8.4 & -8.2 & -3.0 \\
\hline Moldova & 8.8 & -1.5 & -18.0 & -29.1 & -1.2 & -31.2 & -3.1 \\
\hline Mongolia & 4.2 & -2.0 & -9.2 & -9.5 & -3.0 & 2.1 & 6.3 \\
\hline Poland & 0.2 & -11.6 & -7.0 & 2.6 & 3.8 & 6.0 & 6.5 \\
\hline Romania & -5.8 & -7.4 & -12.9 & -8.8 & 1.3 & 3.9 & 6.9 \\
\hline Russia & 3.0 & -2.0 & -12.9 & -19.0 & -12.0 & -15.0 & -4.0 \\
\hline Slovak Republic & 4.5 & -0.4 & -15.9 & -6.7 & -4.7 & 4.8 & 7.4 \\
\hline Slovenia & -2.7 & -4.7 & -8.1 & -5.4 & 1.3 & 5.5 & 4.0 \\
\hline Tajikistan & -2.9 & -1.6 & -7.1 & -29.0 & -11.0 & -21.5 & -12.5 \\
\hline Turkmenistan & -7.0 & -2.3 & -4.8 & -5.3 & -10.2 & -20.0 & -13.9 \\
\hline Ukraine & 4.1 & -3.6 & -11.9 & -17.0 & -13.0 & -21.8 & -11.4 \\
\hline Uzbekistan & 3.7 & 4.3 & -0.9 & -11.0 & -2.4 & -3.5 & -1.2 \\
\hline
\end{tabular}

Sources: National authorities; International Monetary Fund; The World Bank. 
Table 2. Annual Inflation in Transition Economies, 1989-95

(Period average)

\begin{tabular}{|c|c|c|c|c|c|c|c|}
\hline Country & 1989 & 1990 & 1991 & 1992 & 1993 & 1994 & 1995 \\
\hline Albania & 0.0 & 0.0 & 35.5 & 225.2 & 85.0 & 22.6 & 7.8 \\
\hline Armenia & 2.0 & 5.6 & 100.3 & 824.5 & $3,731.9$ & $5,273.4$ & 176.8 \\
\hline Azerbaijan & 2.0 & 7.8 & 61.4 & 912.6 & $1,129.7$ & $1,664.4$ & 411.7 \\
\hline Belarus & 1.7 & 4.5 & 94.1 & 969.9 & $1,187.9$ & $2,222.1$ & 709.0 \\
\hline Bulgaria & 6.4 & 23.9 & 333.5 & 82.0 & 72.8 & 96.0 & 62.1 \\
\hline Croatia & $1,200.0$ & 609.2 & 122.6 & 663.3 & $1,516.0$ & 97.5 & 2.0 \\
\hline Czech Republic & 1.4 & 9.5 & 56.7 & 11.1 & 20.8 & 10.0 & 9.1 \\
\hline Estonia & 2.0 & 23.1 & 212.5 & $1,069.3$ & 89.0 & 47.7 & 28.3 \\
\hline Georgia & 0.9 & 3.3 & 78.5 & 888.3 & $3,126.3$ & $17,246.2$ & 169.0 \\
\hline Hungary & 16.9 & 29.2 & 34.2 & 23.0 & 22.5 & 18.8 & 28.2 \\
\hline Kazakhstan & 2.0 & 4.2 & 90.9 & $1,513.7$ & $1,662.3$ & $1,879.9$ & 176.3 \\
\hline Kyrgyz Republic & 2.0 & 4.2 & 85.0 & 853.8 & $1,208.7$ & 278.1 & 42.8 \\
\hline Latvia & 4.7 & 10.5 & 124.7 & 951.1 & 109.0 & 35.8 & 25.1 \\
\hline Lithuania & 2.1 & 8.4 & 224.7 & $1,020.5$ & 410.4 & 72.1 & 36.5 \\
\hline Macedonia, FYR & $1,246.0$ & 608.4 & 114.9 & $1,692.6$ & 334.5 & 122.6 & 17.4 \\
\hline Moldova & 4.5 & 110.0 & 162.0 & $1,276.4$ & 788.0 & 329.4 & 30.2 \\
\hline Mongolia & 0.0 & 0.0 & 20.2 & 202.8 & 268.4 & 88.3 & 56.8 \\
\hline Poland & 251.1 & 600.0 & 76.4 & 43.0 & 35.3 & 32.2 & 27.8 \\
\hline Romania & 0.9 & 4.7 & 161.1 & 210.3 & 256.0 & 136.8 & 32.0 \\
\hline Russia & 2.4 & 5.7 & 92.7 & $1,353.0$ & 896.0 & 301.1 & 190.2 \\
\hline Slovak Republic & 1.4 & 10.8 & 78.3 & 10.1 & 23.1 & 13.4 & 9.9 \\
\hline Slovenia & $1,306.0$ & 549.7 & 117.7 & 201.3 & 32.3 & 19.8 & 12.8 \\
\hline Tajikistan & 2.0 & 5.6 & 111.6 & $1,159.8$ & $2,194.8$ & 350.4 & 635.4 \\
\hline Turkmenistan & 2.0 & 4.2 & 102.5 & 493.3 & $3,102.4$ & $1,748.9$ & $1,261.5$ \\
\hline Ukraine & 2.0 & 3.0 & 94.1 & $1,210.0$ & $4,734.9$ & 891.2 & 376.4 \\
\hline Uzbekistan & 0.7 & 4.0 & 105.0 & 645.5 & 534.2 & $1,568.3$ & 304.6 \\
\hline
\end{tabular}

Sources: National authorities; International Monetary Fund; The World Bank. 
Table 3. Inflation and Output Performance in Transition Economies, 1989-95

\begin{tabular}{|c|c|c|c|c|c|c|c|}
\hline Country & $\begin{array}{c}\text { Year in } \\
\text { Which } \\
\text { Inflation } \\
\text { was } \\
\text { Highest 1/ }\end{array}$ & $\begin{array}{l}\text { Maximum } \\
\text { Annual } \\
\text { Inflation 1/ }\end{array}$ & $\begin{array}{c}\text { Year in } \\
\text { Which } \\
\text { Inflation } \\
\text { Fell Below } \\
50 \% 1 / 2 /\end{array}$ & $\begin{array}{c}\text { Annual } \\
\text { Inflation } \\
\text { in } 1995 \\
1 /\end{array}$ & $\begin{array}{c}\text { Year in } \\
\text { Which } \\
\text { Output } \\
\text { was } \\
\text { Lowest 3/ }\end{array}$ & $\begin{array}{c}\text { Cumulative } \\
\text { Output } \\
\text { Decline } \\
(1989=100) \\
3 /\end{array}$ & $\begin{array}{c}\text { Cumulative } \\
\text { Output } \\
\text { Growth } \\
\text { Since Lowest } \\
\text { Level 4/ }\end{array}$ \\
\hline Albania & 1992 & 236.6 & 1993 & 6.1 & 1992 & 39.9 & 30.2 \\
\hline Armenia & 1993 & $10,896.2$ & 1995 & 32.1 & 1993 & 66.7 & 10.5 \\
\hline Azerbaijan & 1994 & $1,788.0$ & - & 84.5 & 1995 & 64.0 & - \\
\hline Belarus & 1993 & $1,994.0$ & - & 244.5 & 1995 & 43.9 & - \\
\hline Bulgaria & 1991 & 338.8 & 1995 & 32.9 & 1993 & 27.4 & 3.9 \\
\hline Croatia & 1993 & $1,149.7$ & 1994 & 3.7 & 1993 & 37.0 & - \\
\hline Czech Republic & 1991 & 52.1 & 1992 & 7.5 & 1993 & 21.4 & 7.5 \\
\hline Estonia & 1992 & 946.7 & 1993 & 28.8 & 1993 & 35.3 & 7.2 \\
\hline Georgia & 1993 & $7,487.9$ & - & 62.3 & 1995 & 75.9 & - \\
\hline Hungary & 1990 & 34.6 & n.a. & 28.5 & 1993 & 18.2 & 4.7 \\
\hline Kazakhstan & 1992 & $2,566.6$ & - & 60.4 & 1995 & 58.1 & - \\
\hline Kyrgyz Republic & 1993 & $1,365.6$ & 1995 & 31.5 & 1994 & 50.6 & 1.3 \\
\hline Latvia & 1992 & 958.2 & 1993 & 23.3 & 1993 & 52.0 & 2.4 \\
\hline Lithuania & 1992 & $1,162.6$ & 1994 & 35.5 & 1993 & 32.9 & 4.5 \\
\hline Macedonia, FYR & 1992 & $1,927.3$ & 1995 & 9.3 & 1995 & 48.1 & - \\
\hline Moldova & 1992 & $2,198.4$ & 1995 & 23.8 & 1995 & 62.3 & - \\
\hline Mongolia & 1992 & 325.0 & - & 53.6 & 1993 & 21.9 & 8.6 \\
\hline Poland & 1989 & 639.6 & 1992 & 24.2 & 1991 & 17.8 & 20.2 \\
\hline Romania & 1993 & 295.5 & 1995 & 27.2 & 1992 & 26.4 & 12.5 \\
\hline Russia & 1992 & $2,510.4$ & - & 131.4 & 1995 & 50.3 & - \\
\hline Slovak Republic & 1991 & 58.3 & 1992 & 17.3 & 1993 & 25.5 & 12.6 \\
\hline Slovenia & 1991 & 246.7 & 1993 & 8.6 & 1992 & 16.0 & 9.7 \\
\hline Tajikistan 5/ & 1993 & $7,343.7$ & - & $2,131.9$ & 1995 & 60.3 & - \\
\hline Turkmenistan & 1993 & $9,743.0$ &.- & $1,906.7$ & 1995 & 45.5 & - \\
\hline Ukraine & 1993 & $10,155.0$ & - & 181.4 & 1995 & 57.5 & - \\
\hline Uzbekistan & 1994 & $1,232.8$ & -- & 112.0 & 1995 & 14.3 & - \\
\hline All transition economies $7 /$ & & $2,602.1$ & & 204.2 & & 41.1 & \\
\hline Eastern Europe and Baltics 7/ & & 619.0 & & 19.5 & & 30.6 & \\
\hline FSU and Mongolia 7/ & & $4,585.1$ & & 388.9 & & 51.6 & \\
\hline
\end{tabular}

Sources: IMF staff estimates; national authorities.

1/ Inflation calculated from December to December.

$2 / \mathrm{A}$ "--" indicates that inflation was above 50 percent during the transition years, as of 1995 . In Hungary's case, this criterion is not applicable because inflation was below 50 percent even before 1989 .

3/ Output decline from 1989 to the year in which output was lowest. For countries in which output has not begun to grow, 1995 is taken as the year of minimum output. GDP measured on an annual average basis.

4/ Lowest level refers to the lowest output level reached during 1989-95. A "-." indicates that no positive growth has been recorded as of 1995.

5/ Although inflation in 1994 was only 1.1 percent, it was a temporary phenomenon caused by a shortage of bank notes.

6/ Output revived marginally (0.8 percent) in 1994 and then declined by 1.5 percent in 1995 .

7/ Simple average. 
- Inflation rates have been extremely high in the transition process, higher in the former Soviet Union and the former Yugoslavia than in other countries. In only three countries-the Czech Republic, the Slovak Republic and Hungary-did annual inflation remain below triple digits throughout. In two countries-Armenia and Ukraine - it reached more than 10,000 percent in the year of maximum inflation. ${ }^{9}$ All countries in the former Soviet Union (except the Baltics) experienced inflation of more than 1,000 percent in the year of maximum inflation. Maximum inflation rates were significantly lower in CEE. In most countries, there was an initial jump in inflation, associated with price liberalization and devaluation. This can be thought of as primarily a price level change (see Sahay and Végh (1996)). In most countries, but less so in CEE, inflation increased in subsequent years, but has declined in virtually all countries since then.

- Inflation stabilization is succeeding. By 1995, the average inflation rate (measured December-to-December) in CEE and the Baltics was only 20 percent per annum. Although inflation was about 390 percent in the former Soviet Union and Mongolia, inflation was below half that level in nine of those 12 countries (Table 3 ).

The detailed data presented in Tables $1-3$ are summarized in Figures $1-3 .^{10}$ Panel (a) in Figure 1 shows the (unweighted) average growth rate of measured real GDP since 1989 - which we take to be the year in which the transformation process began-through 1995. Measured growth has on average been negative in every year (but was close to zero in 1995). The growth rate reached a trough in 1992, reflecting the effects of the breakup of the Soviet Union and the collapse of CMEA trade. The growth rate then increased, but remained negative. The corresponding plot for the level of real GDP in panel (a) in Figure 2 shows that, on average, GDP in 1994 was about 60 percent of its initial level. The year 1995 saw a virtual stop to the process of output decline.

It is clear from Tables 1 and 3 that the behavior of output differs between, on the one hand, the CEE and Baltic countries (EEB) and, on the other hand, the countries of the former Soviet Union (excluding the Baltics) and Mongolia (FSUM). We therefore present output profiles in levels and growth rates for these groups of countries in Figures 1 and 2 in panels (b) and (c), respectively. The average level of output reached a minimum in EEB in 1993, and has since begun to grow (Figure 2, panel (b)). At that point, output had fallen 30 percent below the 1989 level. In the FSUM countries, output continued to fall through 1995, albeit at a declining rate. The level in 1995 was less than 50 percent of the 1989 level.

\footnotetext{
${ }^{9}$ Inflation in these countries would have met the classic Cagan definition of hyperinflation, more than 50 percent per month. Serbia, for which we do not have complete data, also suffered from a hyperinflation.

${ }^{10}$ For reasons explained later Turkmenistan is excluded from the time profiles.
} 


\section{Figure 1. Real GDP Growth Profiles in Calendar Time 1/}

1 (a). All transition economies

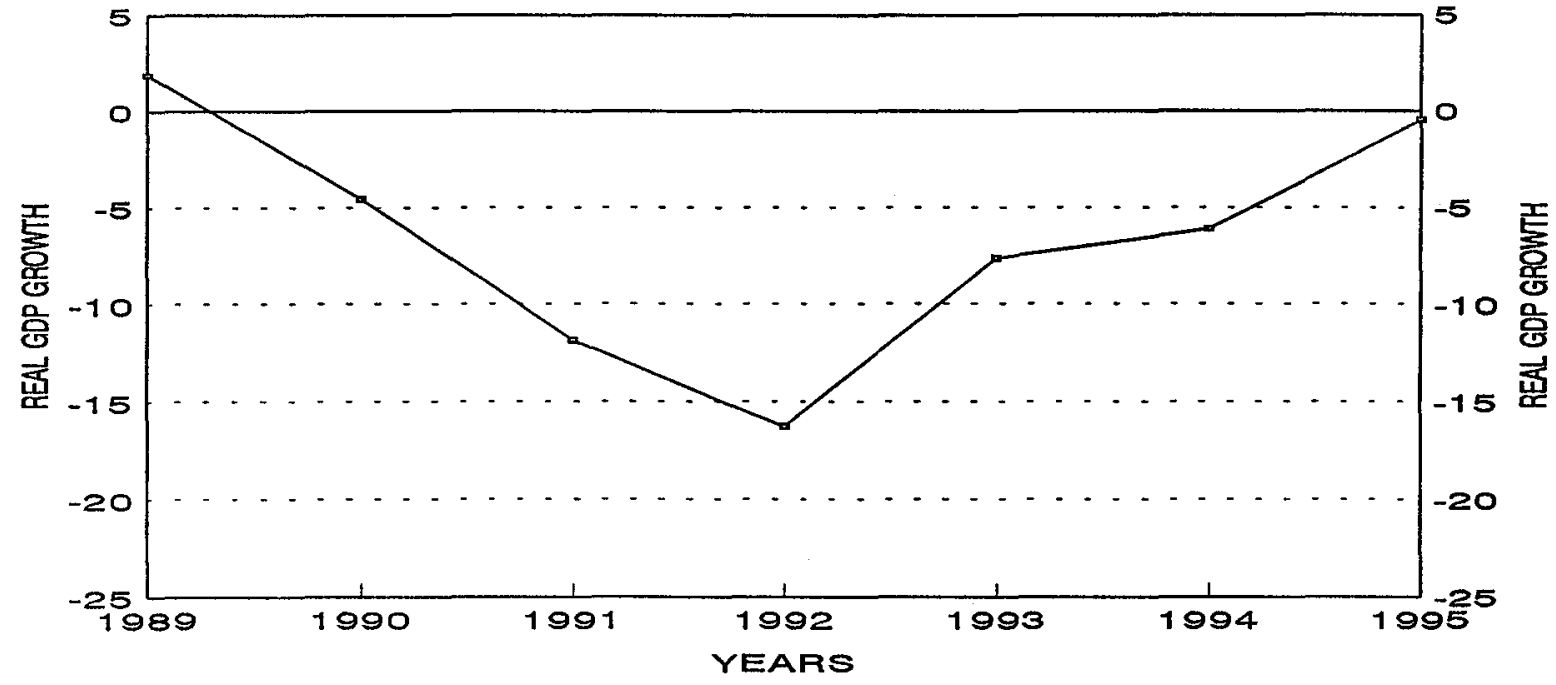

1 (b). Eastern Europe and Baltics

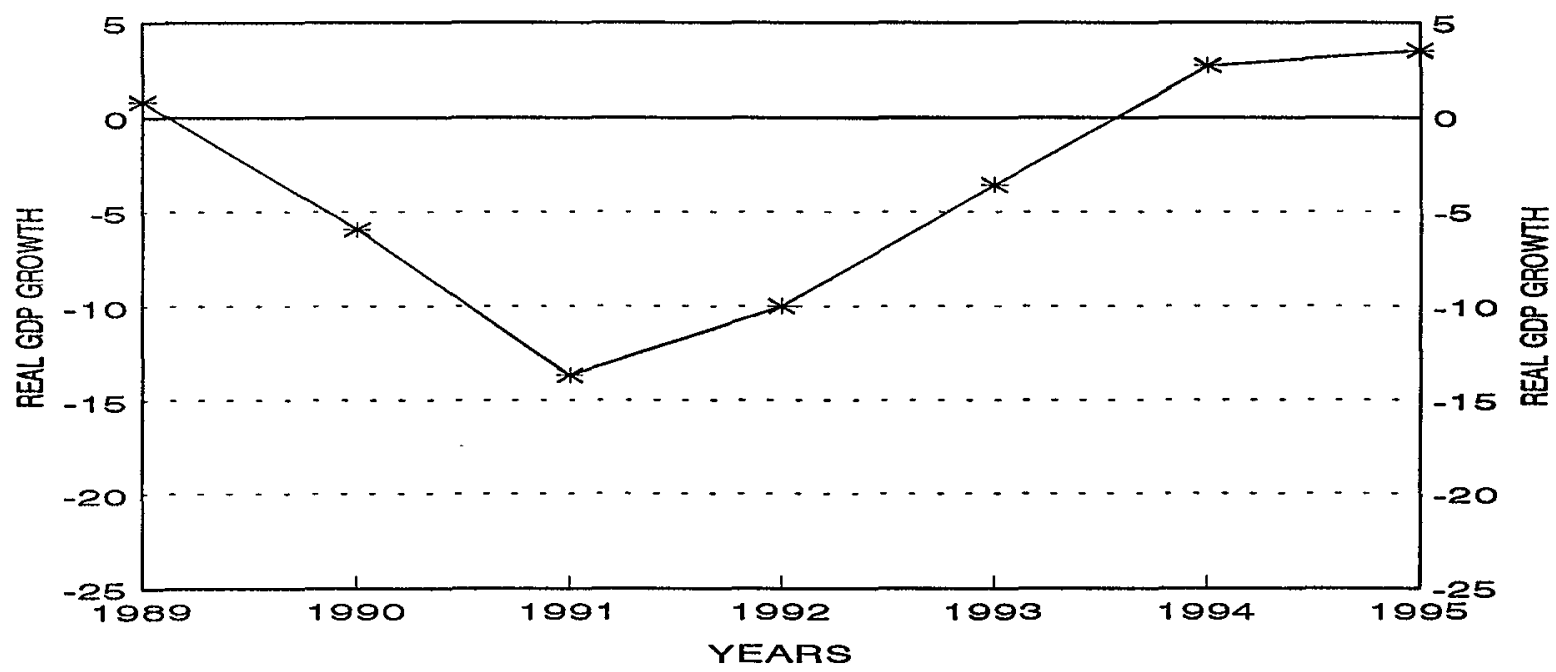

1(c). Former Soviet Union and Mongolia

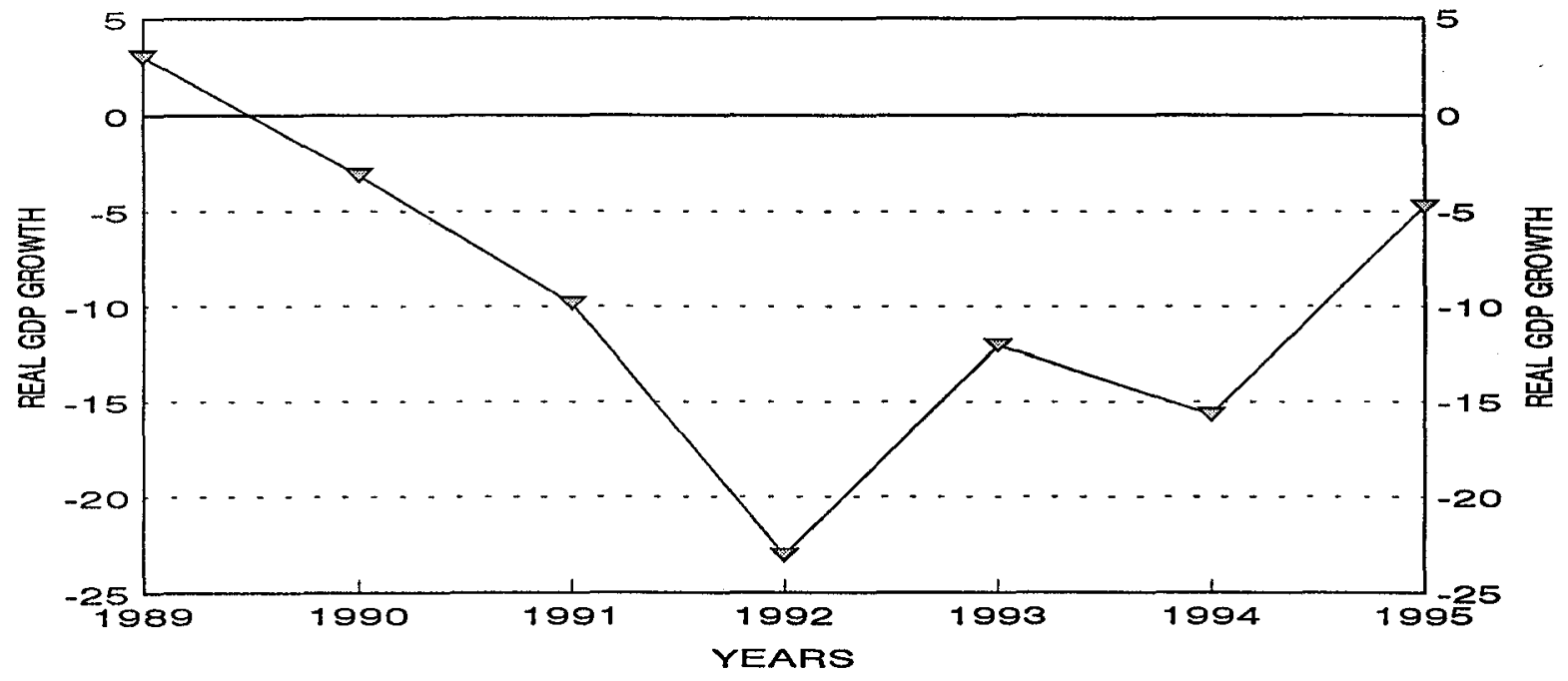

1/ The sample comprises the 26 countries mentioned in the text, except Turkmenistan which had no stabilization program as of 1995. 
Figure 2. Real GDP Index Profiles in Calendar Time $(1989=100) 1 /$

2(a). All transition economies
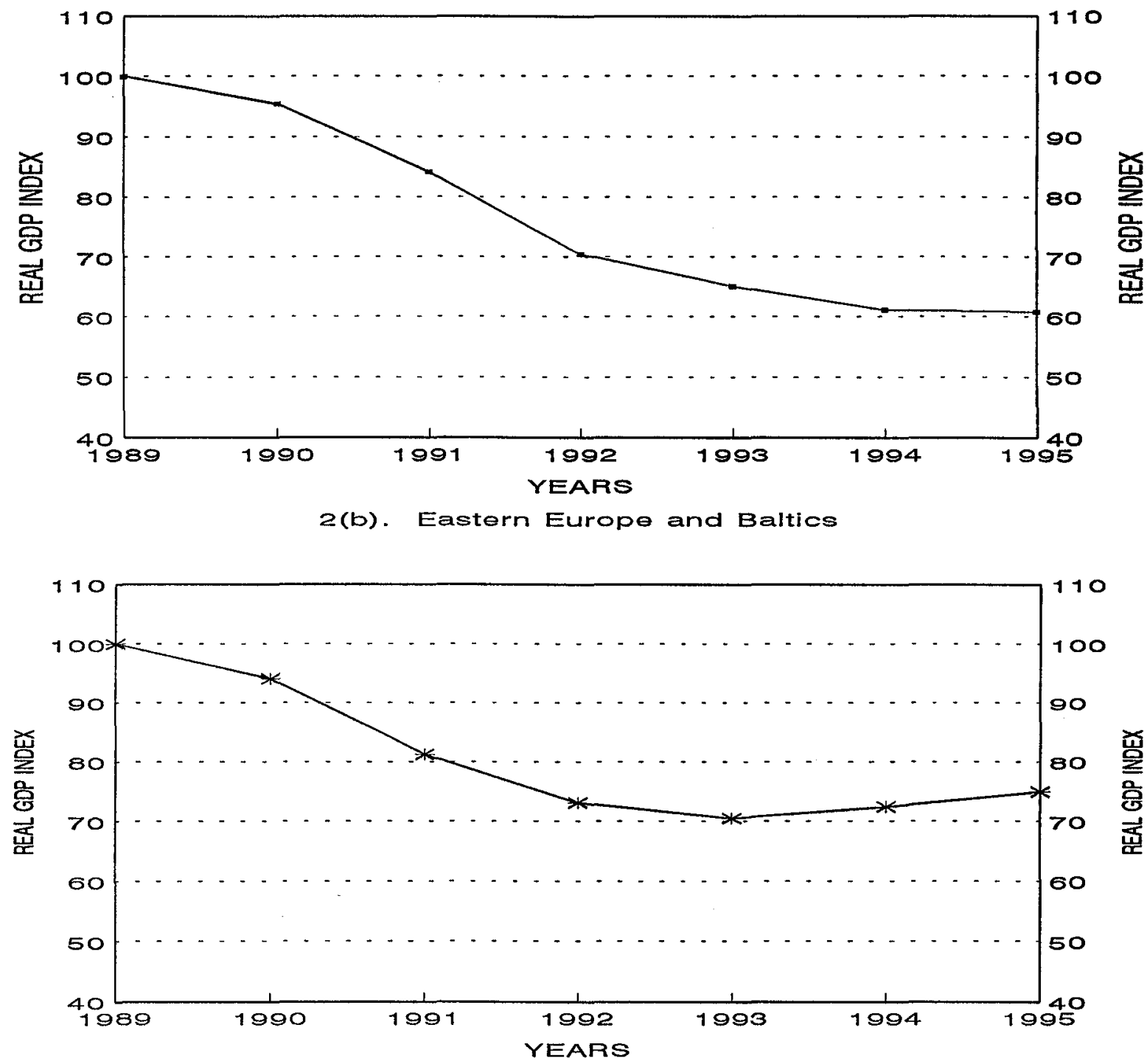

2(c). Former Soviet Union and Mongolia

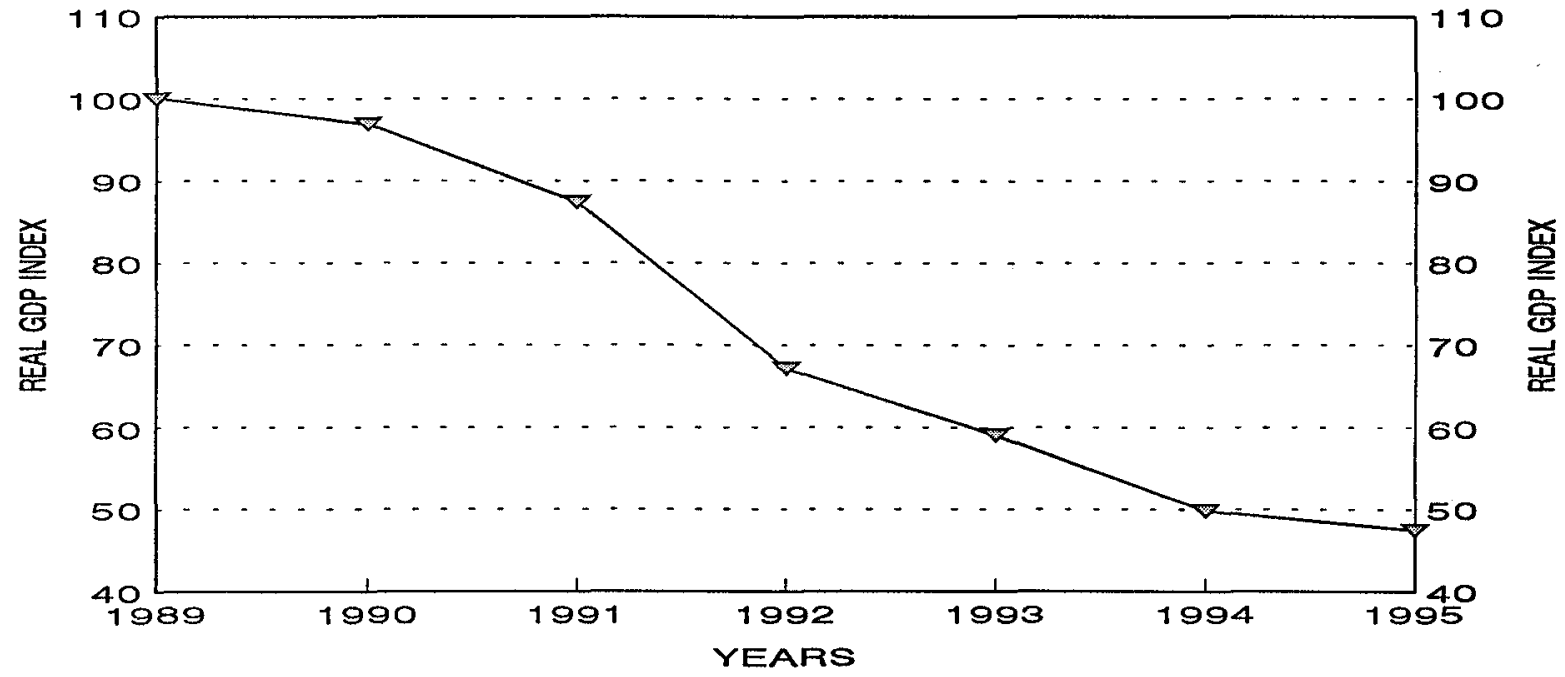

1/ The sample comprises the 26 countries mentioned in the text, except Turkmenistan which had no stabilization program as of 1995 . 
Figure 3. Average Inflation Profiles in Calendar Time 1/ 3 (a). All transition economies

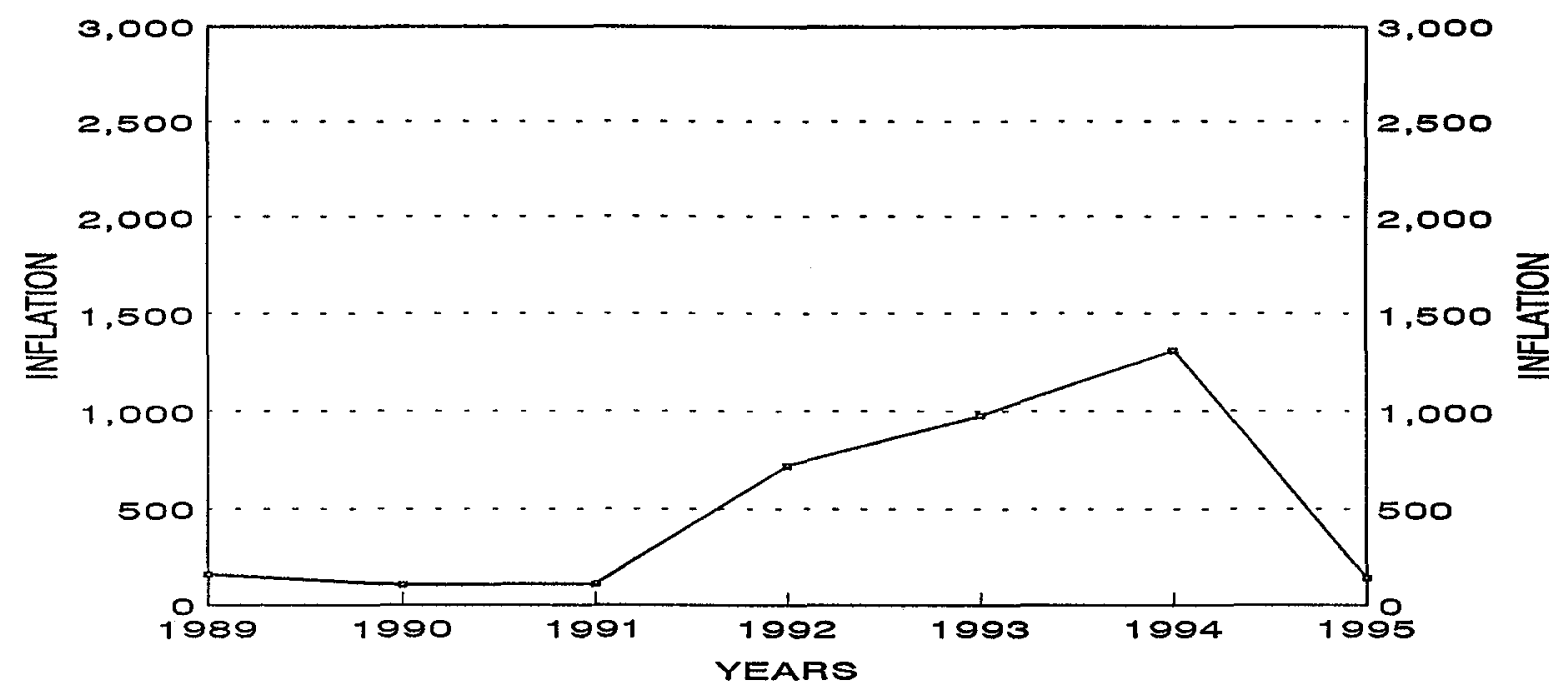

3(b). Eastern Europe and Baltics

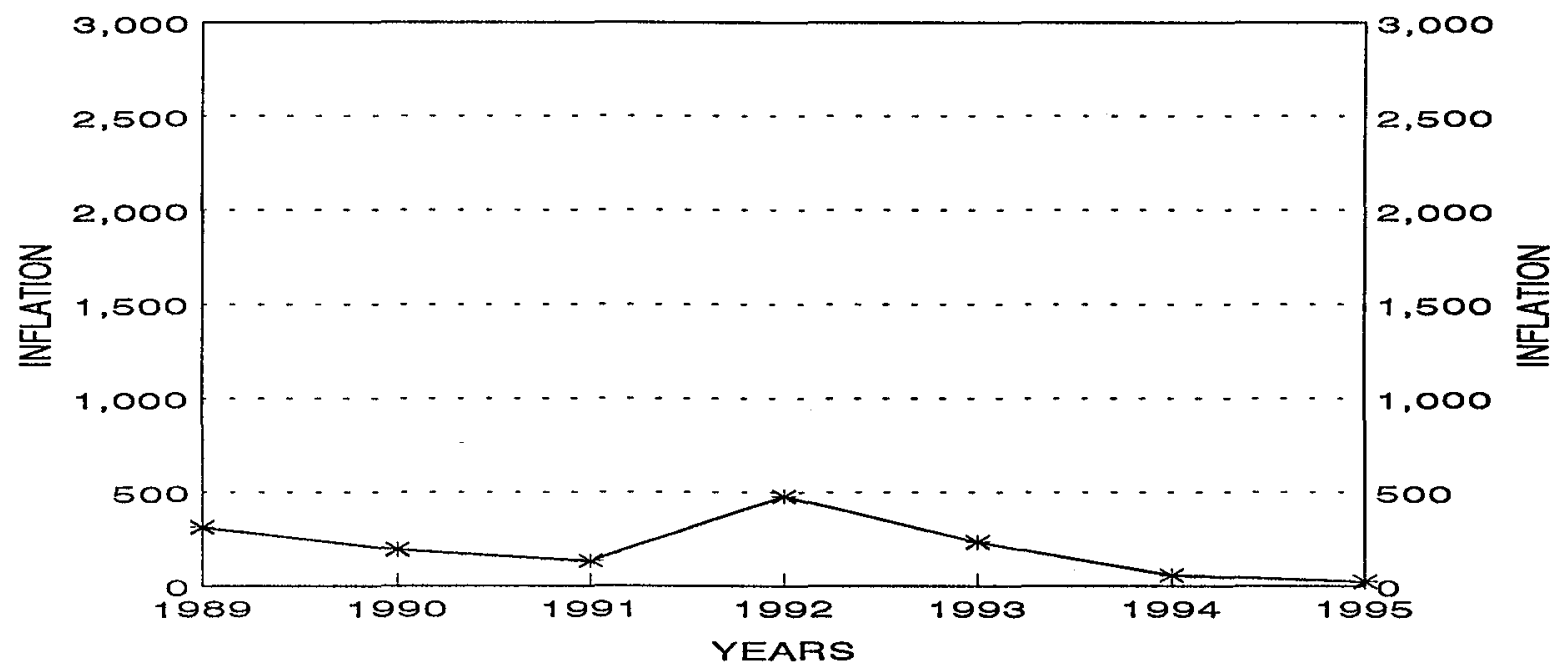

3(c). Former Soviet Union and Mongolia

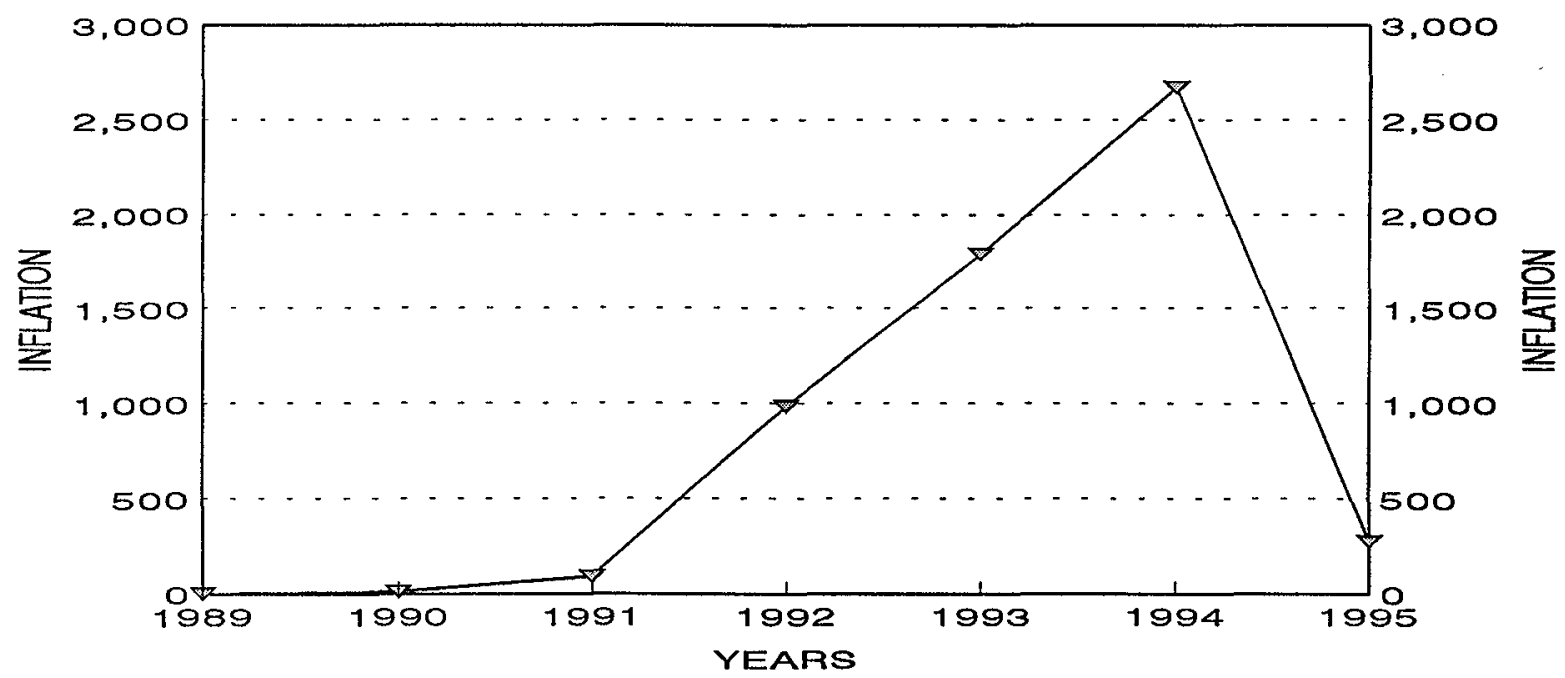

1/ The sample comprises the 26 countries mentioned in the text, except Turkmenistan which had no stabilization program as of 1995. 
The pattern of inflation since the start of the transition process is presented in Figure 3. Inflation increased dramatically from 1991 to 1994 . The process turned around in 1995 when average inflation declined sharply. Separate profiles for the EEB and FSUM countries show that inflation in the EEB remained well below the levels in the FSUM, and turned down sooner.

\section{B. Stabilization and Growth}

Figures 1-3 highlight the differences between the output and inflation profiles of two groups of countries: Eastern Europe and the Baltics, and the former Soviet Union and Mongolia. In this section, we argue that one key difference between the two groups is the date in which countries started their stabilization programs. In so doing, we will also argue that there is a typical profile of output and inflation that may be expected to develop around the time of stabilization.

As Table 4 documents, countries started their stabilization plans at different dates. According to IMF economists working on those countries, stabilization attempts have been implemented in 25 of the 26 countries, with Turkmenistan being the exception. For each country we list the date on which the stabilization program was implemented. The date given is the starting date of a country's inflation stabilization program, and not necessarily the starting date of an IMF program. When several stabilization attempts have been made (which was the case in six countries), we take the most serious attempt (as of end-1995) as the reference date. ${ }^{11}$

The third column of Table 4 indicates the exchange rate regime adopted during the stabilization program. Countries that announced an exchange rate peg, including a crawling peg, are classified as having a fixed rate regime. In two cases-Croatia and the former Yugoslav Republic of Macedonia (FYRM) - the exchange rate regime is classified as a peg on the basis of the policies actually implemented, even though the authorities did not explicitly announce it as such. Several FSU countries (Armenia, Azerbaijan, Belarus, Georgia, Kazakhstan, and the Kyrgyz Republic) that began their stabilization programs under a flexible exchange rate regime had begun to peg de-facto their currencies to the U.S. dollar by 1995 and are listed as flexible/fixed. Latvia, Lithuania, and Russia are also listed as flexible/fixed because they had flexible rate regimes at the time of stabilization but later moved to a fixed rate.

\footnotetext{
${ }^{11}$ The choice of a particular stabilization date, when there have been multiple attempts, necessarily requires a judgment call. We have tried to make this judgment on the basis of the policy package associated with the stabilization attempt, rather than on ex post inflation performance.
} 
Table 4. Stabilization Programs in Transition Economies, 1989-95

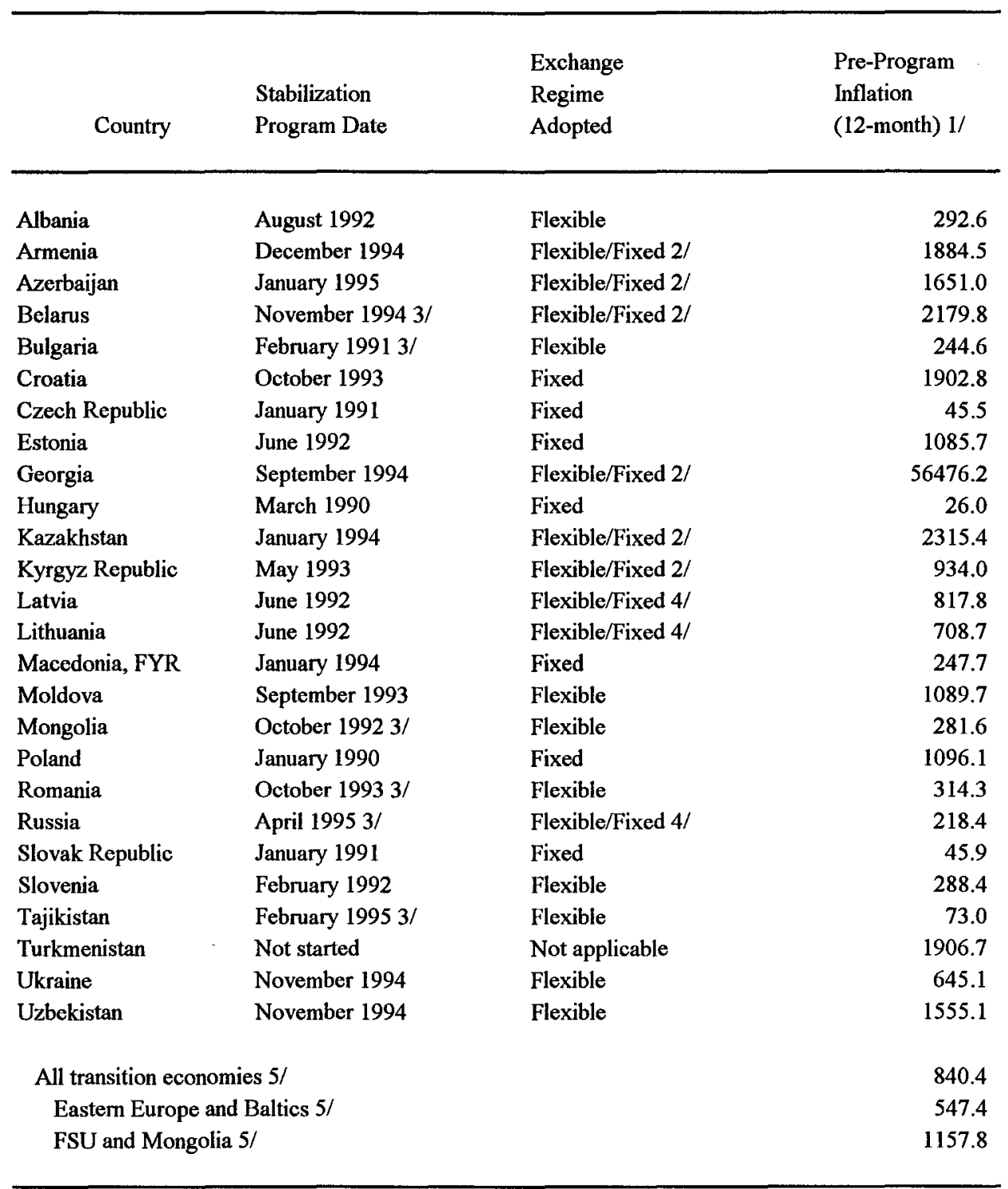

Sources: IMF estimates; The World Bank; national authorities; De Melo, Denizer, and Gelb (1995).

1/ Inflation in the twelve months previous to the month of the stabilization program. For Turkmenistan, the figure is for the latest year available (1995).

2/ As of 1995, these countries adopted a de-facto peg to the U.S. dollar.

3/ The date of the most serious stabilization attempt.

4/ The Latvian currency was pegged to the SDR in February 1994; Lithuania adopted a currency board in April 1994. Russia announced an exchange rate corridor in July 1995. All three countries had flexible exchange rate regimes prior to these dates.

$5 /$ Simple averages for all variables; excludes Georgia's extreme inflation value. 
Given that countries started their stabilization programs at different points in chronological time, we have computed output and inflation profiles relative to the date of stabilization; that is, in "stabilization time." ${ }^{12}$ Stabilization time is denoted by $\mathrm{T}+\mathrm{j}$, where $\mathrm{T}$ is the year in which the stabilization program was implemented and $\mathrm{j}$ is the number of years preceding or following the year of stabilization. ${ }^{13}$

The shift from chronological time in Figures 1-3 to stabilization time in Figures 4-6 changes the picture dramatically. Panel (a) in Figure 4 shows large negative rates of GDP growth until the year of stabilization. Output growth then begins to recover, with GDP growth becoming positive two years after stabilization. The corresponding pattern in terms of levels is shown in panel (a) in Figure 5. Panel (a) in Figure 6 shows that inflation, in turn, peaks in the year before stabilization, falls sharply when the stabilization plan is implemented, and remains low thereafter.

Since there were systematic differences in the date of stabilization between the countries of the former Soviet Union and those of eastern Europe, the stabilization time profiles in Figures 4-6 represent a changing population of countries. In particular, the observations for $\mathrm{T}+3$ and $\mathrm{T}+4$ come from eastern Europe and the Baltics, rather than from the other republics of the former Soviet Union.

We now want to examine whether the time profiles, where they overlap, are essentially similar. In Figures 4 and 5 we present output growth and level profiles in stabilization time for the two groups of countries. Growth in the EEB countries was negative and declining up to the year of stabilization (Figure 4, panel (b)). Real GDP growth turned positive two years after stabilization. Indeed, by 1996 output has begun to grow in all these countries. Output levels for EEB are shown in Figure 5 in panel (b). For the FSUM group, panel (c) in Figures 4 and 5 show that the level of output has been declining continuously. The shape of the real GDP index profile is very similar to that for the EEB countries. Of course, average GDP for the EEB countries never fell as low as it did for the FSUM countries.

\footnotetext{
${ }^{12}$ Of the 26 countries in the sample, Turkmenistan was excluded in computing profiles in stabilization time because there has been no stabilization attempt as of end-1995.

${ }^{13}$ The number of observations for each year in stabilization time is likely to differ (see Fischer, Sahay, and Végh (1996a) for details). For the purposes of the time profiles shown in the paper, we report averages only for those years in stabilization time for which there are at least 3 observations.
} 
Figure 4. Real GDP Growth Profiles in Stabilization Time 1/ 4(a). All transition economies
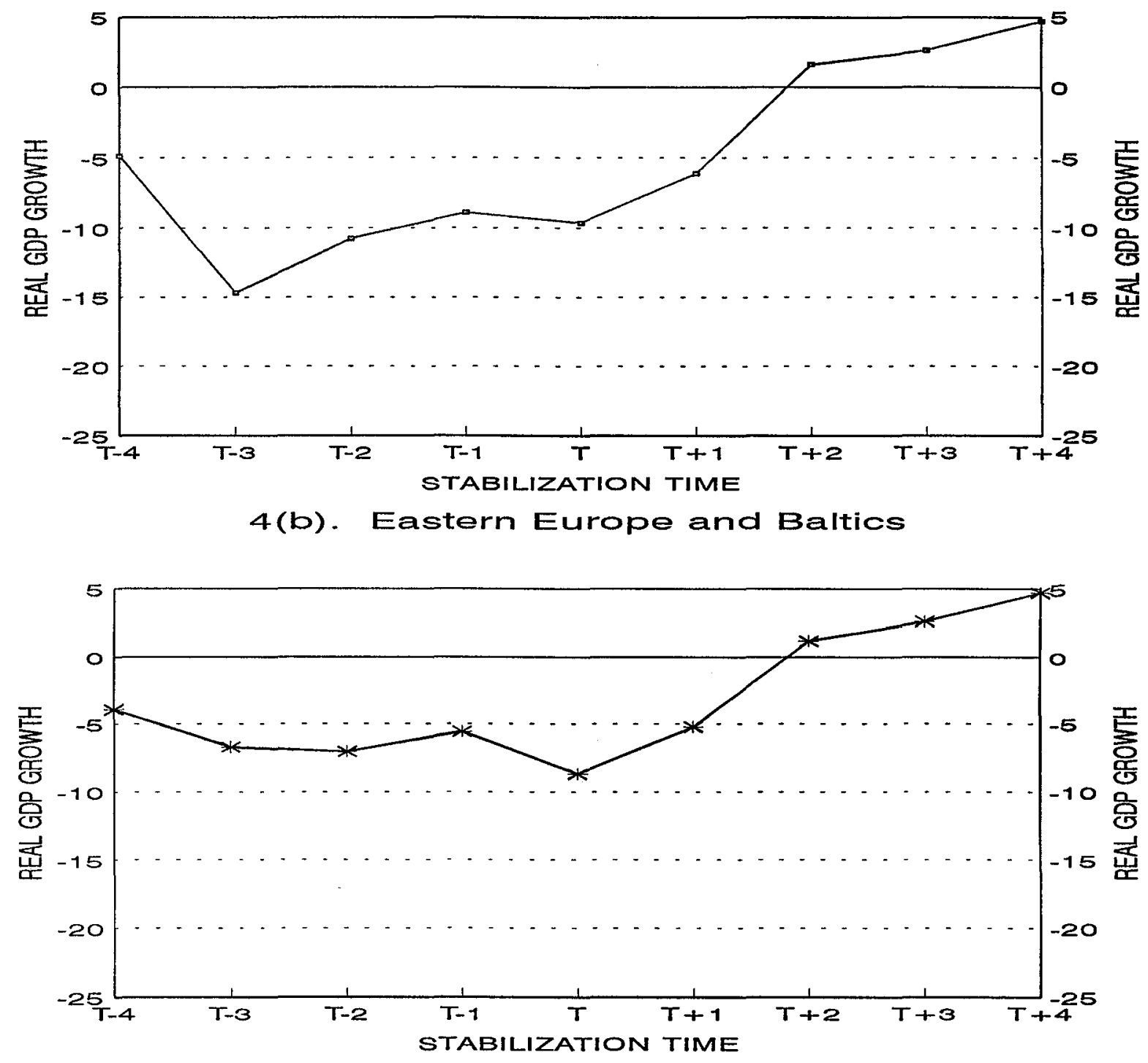

4(c). Former Soviet Union and Mongolia

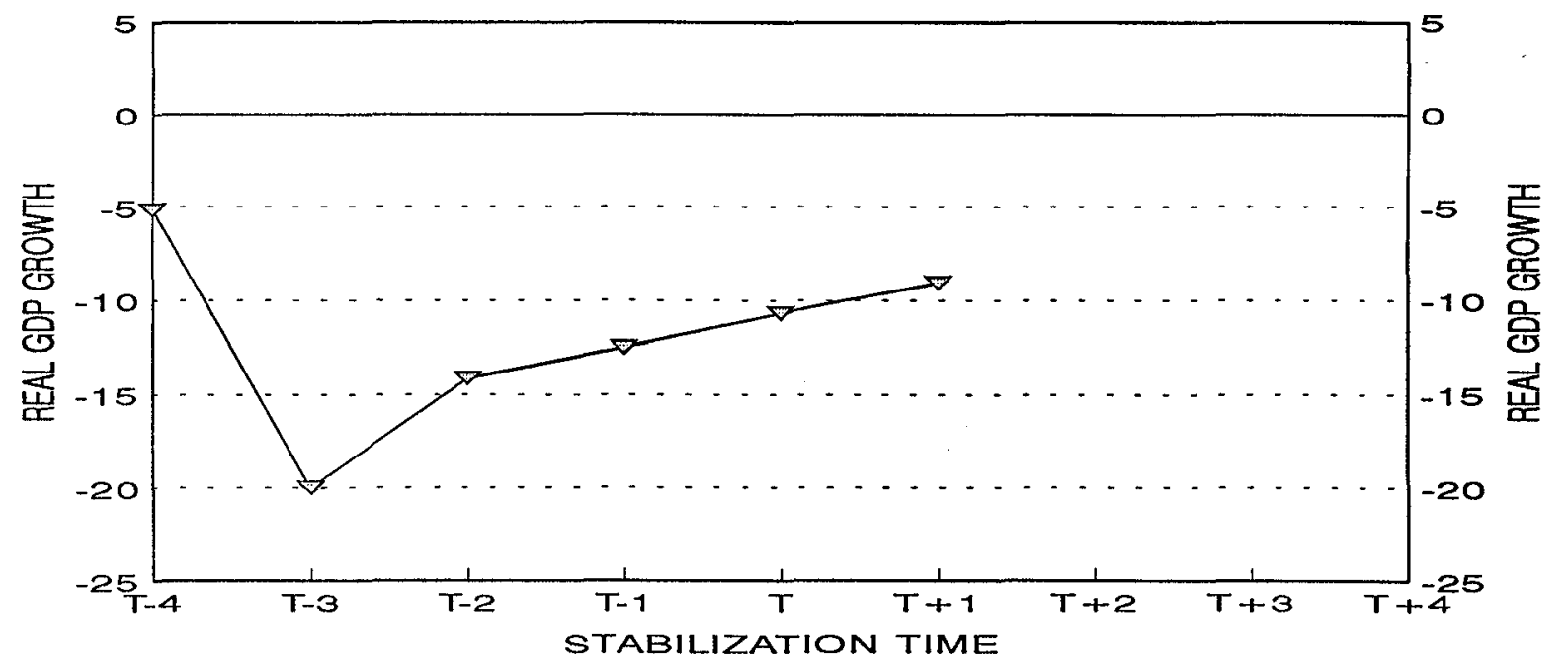

1/ The sample comprises the 26 countries mentioned in the text, except Turkmenistan which had no stabilization program as of 1995.

Stabilization time $T$ is defined as the year the stabilization program started. For details see text. 
Figure 5. Real GDP Index Profiles in Stabilization Time 1/ 5(a). All transition economies $(T-4=100)$
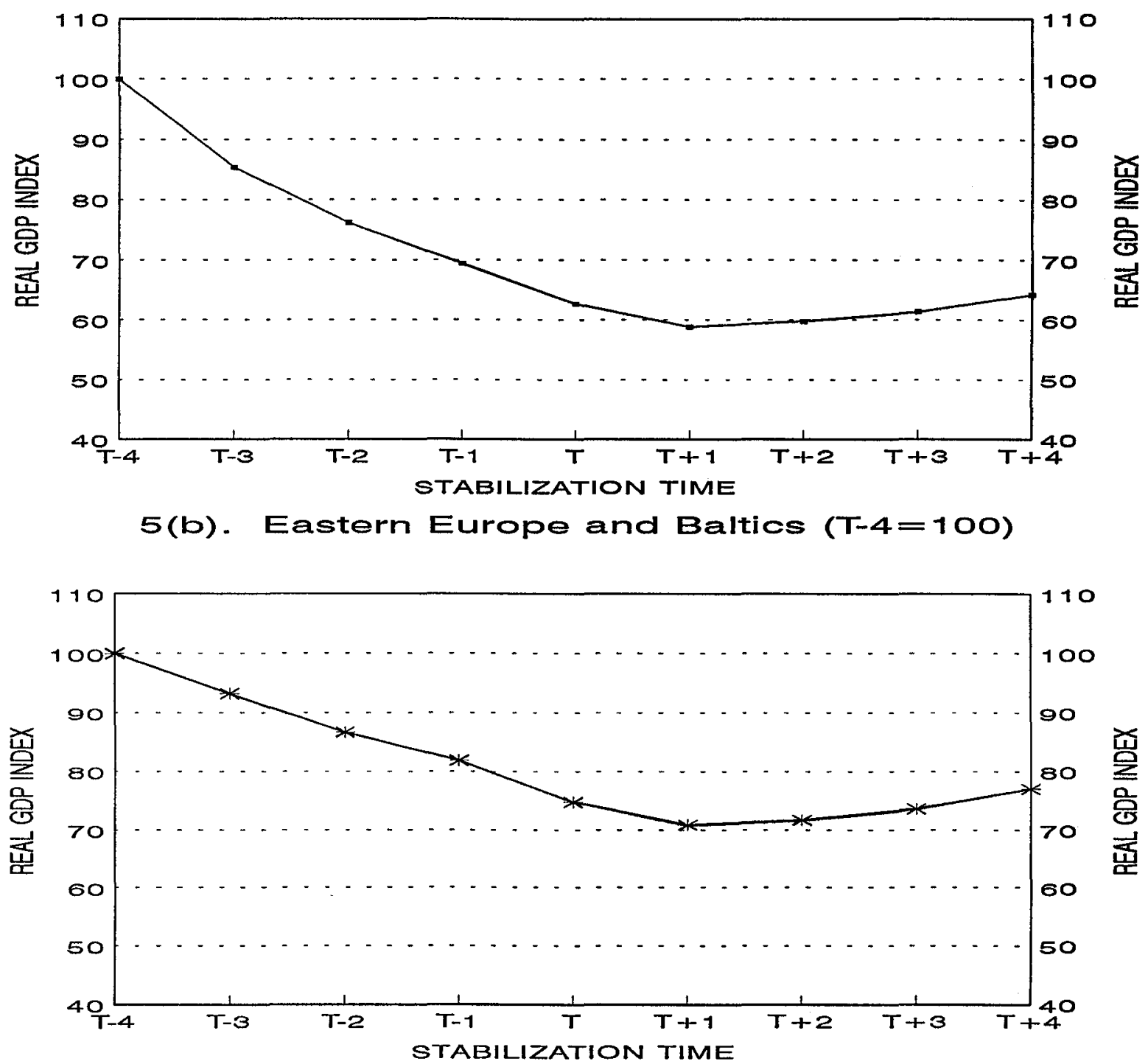

5(c). Former Soviet Union and Mongolia (T-4=100)

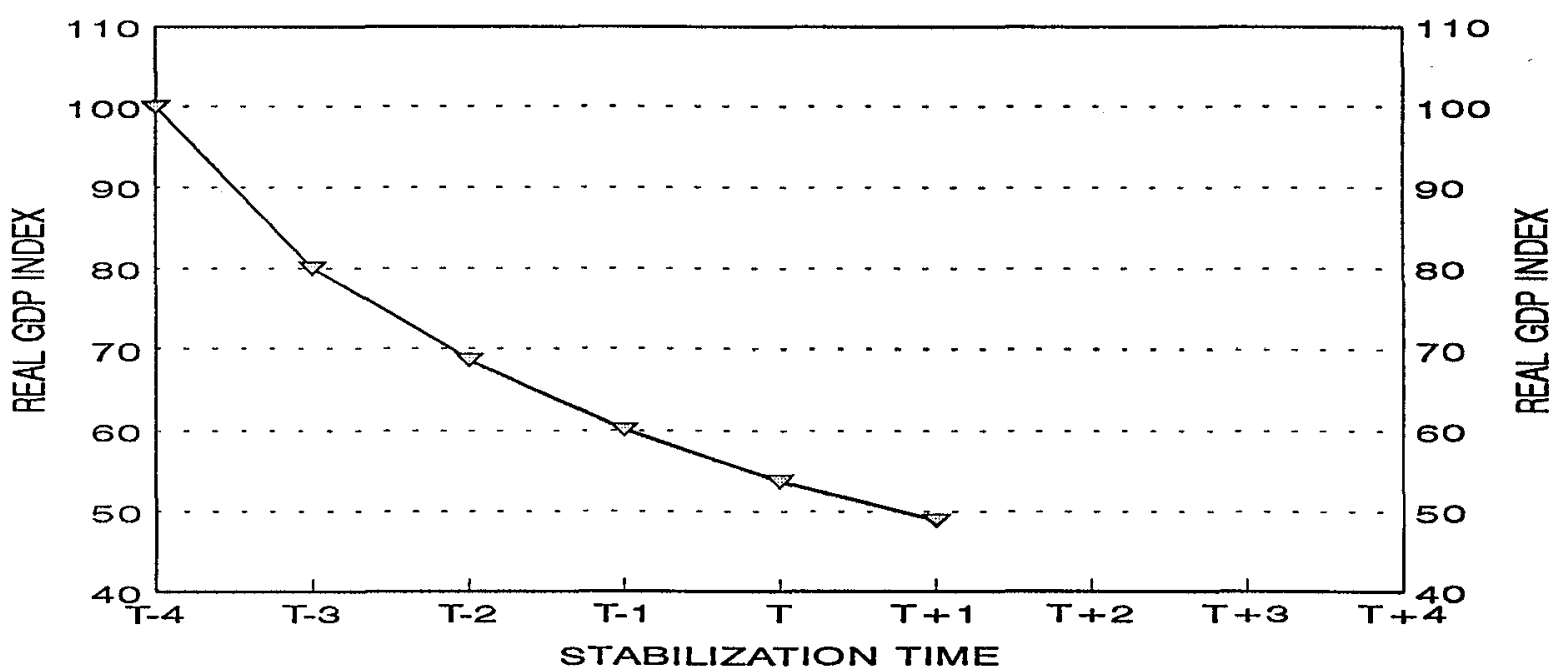

1/ The sample comprises the 26 countries mentioned in the text, except Turkmenistan which had no stabilization program as of 1995.

Stabilization time $T$ is defined as the year the stabilization program started. For details see text. 
Figure 6. Average Inflation Profiles in Stabilization Time 1/ 6 (a). All transition economies
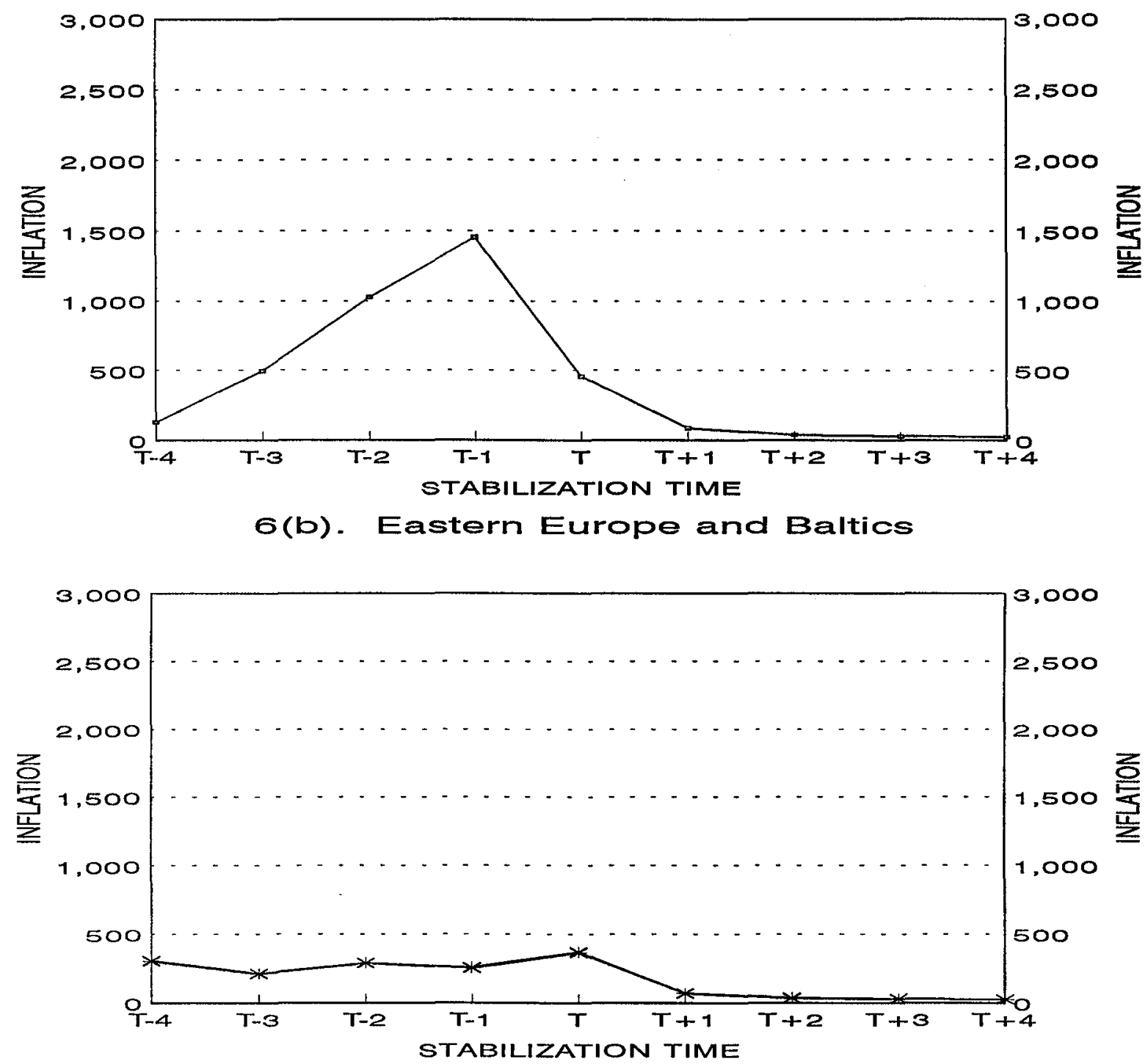

6(c). Former Soviet Union and Mongolia

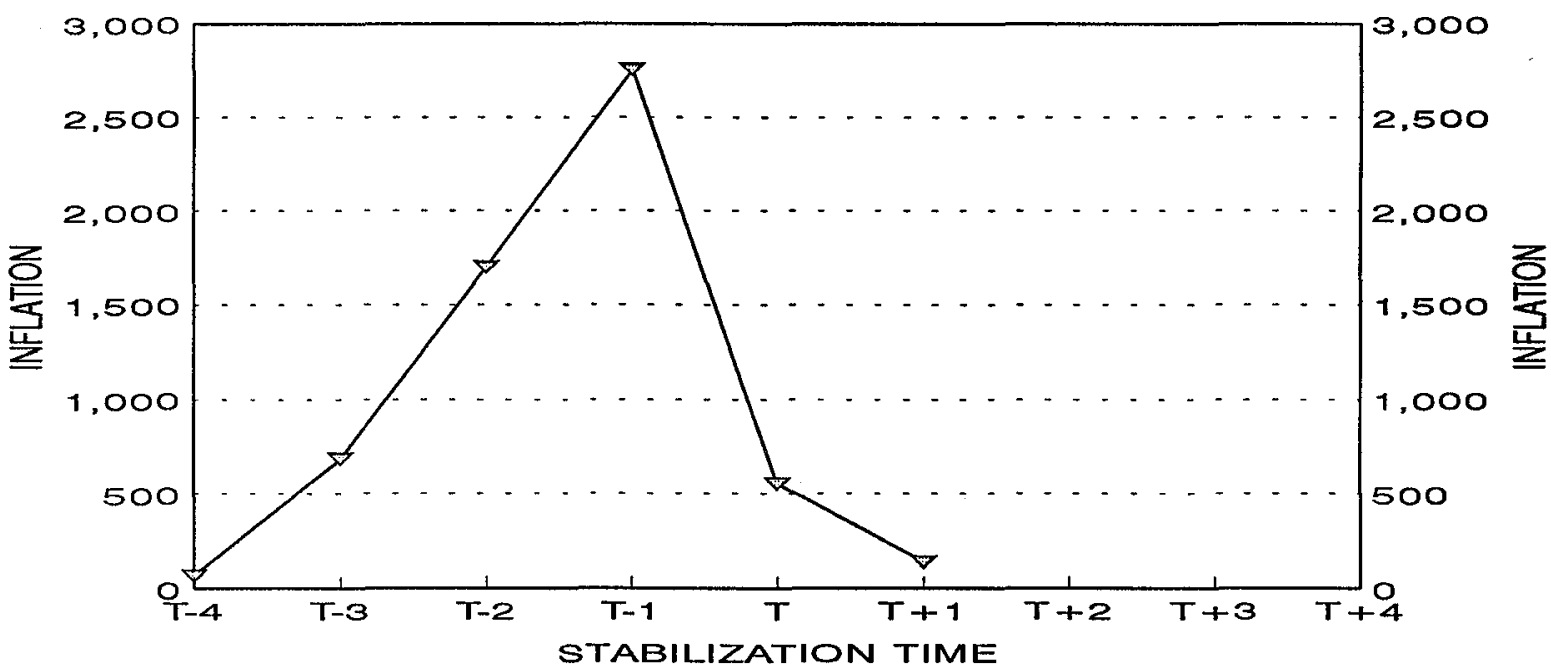

1/ The sample comprises the 26 countries mentioned in the text, except Turkmenistan which had no stabilization program as of 1995.

Stabilization time $T$ is defined as the year the stabilization program started. For details see text. 
Inflation profiles in stabilization time are presented in Figure 6. The pattern shown in the different panels is similar, with inflation peaking one year before or in the year of stabilization and then declining sharply. However, inflation in the EEB economies never reached the levels that it did in the former Soviet Union. After stabilization, the average rate of inflation in EEB quickly fell below 100 percent, and then below 50 percent, although the scale of the chart makes this difficult to discern.

Underlying the behavior of output and inflation are significant changes in fiscal policy. These are illustrated in Figure 7. In chronological time, for the whole sample (panel a), the deficit increased markedly until 1992, and improved afterwards. Panel (b) in Figure 7, in stabilization time, shows very large average fiscal deficits early on, followed by a significant improvement in the years leading to stabilization and, with a brief interruption, continued improvement. In stabilization time, the profiles for the two groups of countries are broadly similar, but the fiscal situation in FSUM was on average significantly worse than that in EEB. Overall, the behavior of fiscal balances roughly mirrors the behavior of inflation.

The simple - but essential - message that emerges from this section is that real GDP rebounds following inflation stabilization, which in turn appears highly correlated with the improvement in the public finances. We shall now seek to refine the basic story.

\section{DETERMINANTS OF GROWTH AND INFLATION IN THE TRANSITION}

In this section we present some simple econometric evidence on the determinants of growth and inflation during the transition process. Regressions were run with the average annual rate of growth of real GDP and the logarithm of annual end-of-period inflation as the dependent variables. As explanatory variables, we included macroeconomic policies (exchange rate and fiscal policy), the extent of structural reforms, and exogenous shocks (the effects of the CMEA collapse in 1991 and the break up of the Soviet Union in January 1992). ${ }^{14}$

The exchange rate regime (as listed in Table 4) is characterized by a dummy variable which takes on a value of one when the exchange rate is fixed, and zero otherwise. If the exchange rate regime changed during the sample period 1992-95 (as in some former Soviet Union countries), we adopted the procedure of assigning the value of one (zero), if the exchange rate regime was fixed (flexible) for more than six months in that year.

\footnotetext{
${ }^{14}$ See Fischer, Sahay, and Végh (1995a) for details on data definitions and methodology.
} 
Figure 7. Fiscal Balance Profiles (Percentage of GDP) 1/ 7(a). Calendar time

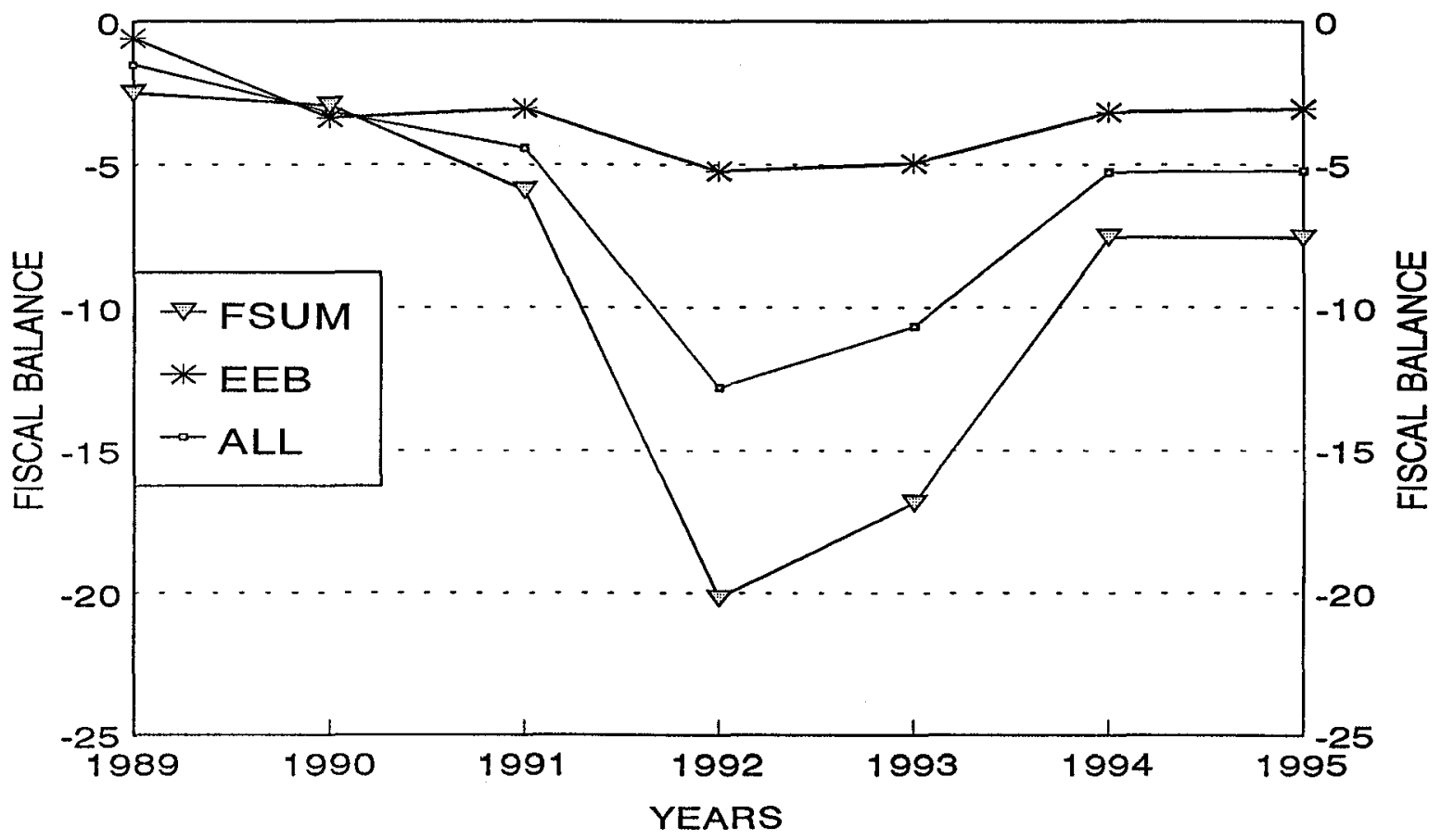

7(b). Stabilization time

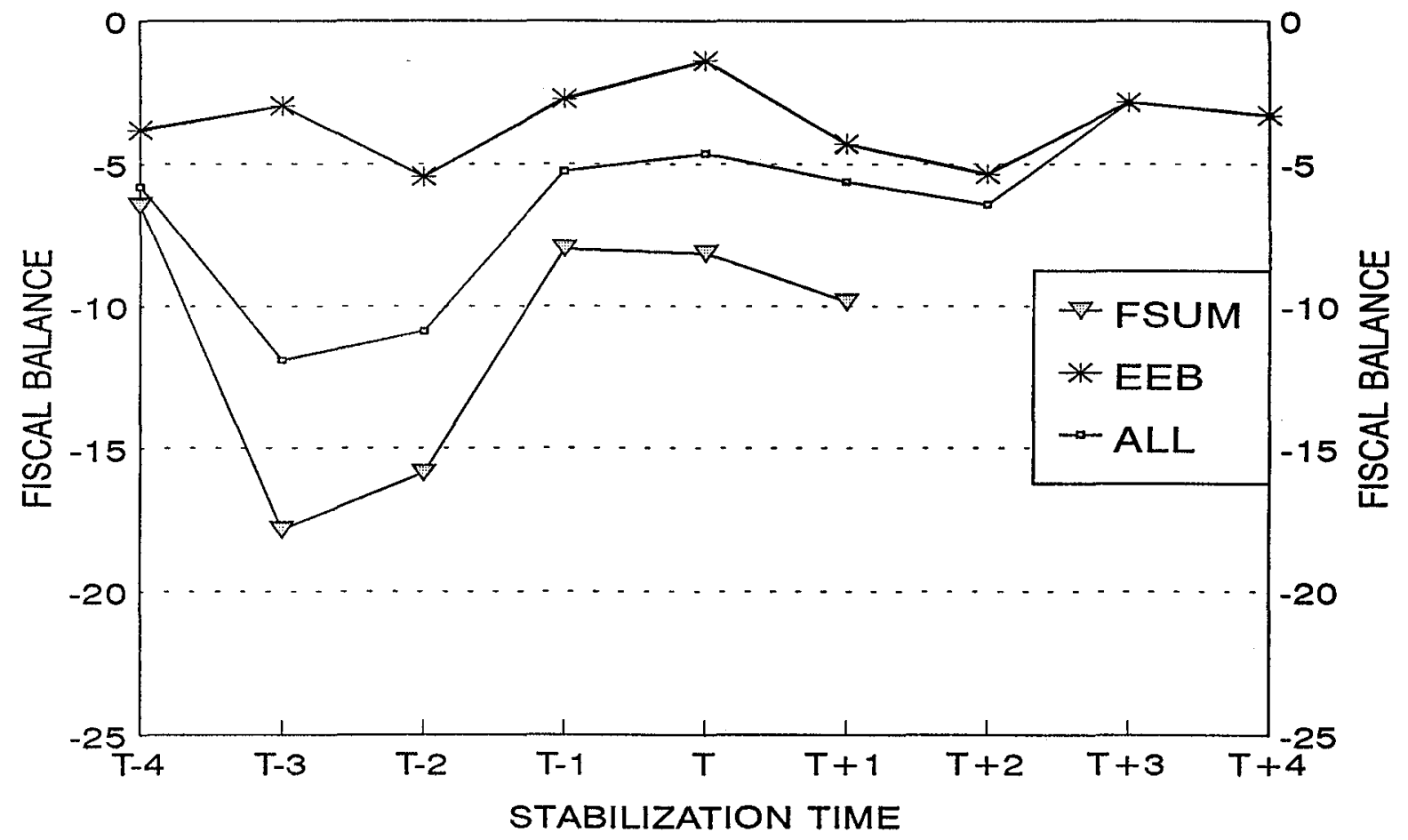

1/ The sample comprises the 26 countries mentioned in the text, except Turkmenistan which had no stabilization program as of 1995.

Stabilization time $T$ is defined as the year the stabilization program started. For details see text. 
The extent of structural reforms in each year was measured as an economic liberalization index, LIBERAL (as computed by de Melo, Denizer, and Gelb (1995) for the period 1989-.95 based on information presented in the 1994 and 1995 Transition Report), where zero represents an unreformed planned economy and 1 represents a fully reformed economy. This index is a weighted average of three indices: price liberalization and competition (LII, with a weight of 0.3 ), trade and foreign exchange regime (LIE, with a weight of 0.3 ), and privatization and banking reform (LIP, with a weight of 0.4$)$. On the basis of the yearly liberalization index, De Melo, Denizer, and Gelb (1995) construct a cumulative liberalization index (CLI) to capture the speed and depth of reforms over the 1989-95 period. The trade disruptions caused by the breakups of the CMEA and the Soviet Union in 1992 were summarized by a dummy variable (Y92), which takes a value of 1 for the year 1992 and zero otherwise.

For the purpose of this econometric exercise, we considered the period 1989-95 period and thus excluded the period 1989-91. The main reason for excluding the period 1989-91 is that we found it difficult to characterize macroeconomic policy in more than half the countries before 1992-namely in the former Soviet Union and Albania. In particular, it makes little sense to use the same definitions for the exchange rate regime of the pre and post-reform period.

To carry out the econometric analysis, we pooled the cross-section and time series data for all 25 countries for four years, 1992-95. ${ }^{15}$ To capture fixed effects, we allowed the intercept to vary across countries. This formulation enables us to test whether there are differences across countries (presumably reflecting omitted variables), modeled as parametric shifts in the regression function.

The role of the exchange rate regime in stabilization and growth has long been a subject of controversy. A strong case can be made for using the exchange rate as a nominal anchor in reducing inflation in transition economies (Sahay and Végh (1996) and Hansson and Sachs

${ }^{15}$ To be specific, the estimated equation for the pooled cross-section time-series regressions takes the form:

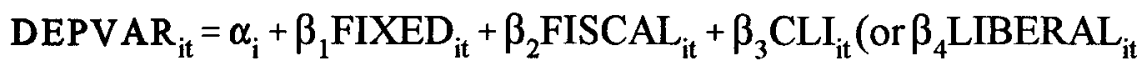
or $\beta_{5} \mathrm{LIE}_{\mathrm{it}}$ or $\mathrm{B}_{6} \mathrm{LII}_{\mathrm{it}}$ or $\left.\beta_{7} \mathrm{LIP} \mathrm{it}_{\mathrm{it}}\right)+\beta_{8} \mathrm{Y}_{92} 2_{\mathrm{it}}+\mathrm{u}_{\mathrm{it}}$,

where DEPVAR is GDP growth, as defined above; $I(=1, . .25)$ indexes the country; $t(=1992$, 1993, 1994, 1995) indexes time; and $\mathrm{u}$ is an error term assumed to be i.i.d over $\mathrm{I}$ and $\mathrm{t}$ and uncorrelated with the explanatory variables. FIXED is the exchange rate dummy; FISCAL is the government balance variable (thus, a fiscal deficit takes on a negative value); CLI is the cumulative value of the liberalization index; LIBERAL is the value of the weighted liberalization index; LIE is the liberalization index for trade and foreign exchange regime; LII is the liberalization index for price and competition; LIP is the liberalization index for privatization and banking reform; and Y92 is the time dummy for 1992. 
(1995)). This case is buttressed by the fact that exchange rate-based stabilizations have often been associated with growth rather than recession (Rebelo and Végh, 1995; Easterly, 1995).

Our a priori expectation, therefore, was that countries with fixed exchange rate regimes would experience a quicker revival of output. We also expected growth to be lower the larger the fiscal deficit and the smaller the extent of market-oriented reforms.

While we will use our regressions for drawing lessons, we should note that causation is in some cases not self-evident. For instance, it is surely the case that growth may feed back into fiscal balances through higher revenues. We find less persuasive the argument that low inflation countries may have chosen a fixed exchange rate. In any event, good instruments are not easy to come by. Our regressions should therefore not be viewed as reflecting deep structural relations but rather as a convenient way of presenting the data. Further qualification is needed given that the data are sparse and preliminary.

Table 5 reports the regression results obtained from the fixed effects model. In all cases, country-specific effects turned out to be highly significant (using a likelihood ratio test), indicating that there were some differences across countries which are not captured by the explanatory variables. The regression results indicate that a pegged exchange rate regime, tighter fiscal policy, and most measures of structural reforms affected growth positively. Thus, we find-not surprisingly - that countries that achieved macroeconomic stabilization (through the use of fixed exchange rates and tight fiscal policy) and undertook deeper reforms are growing faster during the transition. We also found that the break up of the CMEA and the Soviet Union had a very large negative impact on growth. The inflation regressions strongly support the notion that a fixed exchange rate regime and lower fiscal deficits helped in quickly stabilizing high inflation. Thus, while there is little doubt that correcting the underlying fiscal imbalances is essential for the success of a stabilization program, a strong nominal anchor appears to be an important component as well. Structural reforms have also helped in lowering inflation. 
Table 5. Fixed Effects Model for 25 Transition Economies, 1992-95

(T-Statistics in parenthesis)

\begin{tabular}{|c|c|c|c|c|c|c|c|c|c|c|c|c|c|c|}
\hline & \multicolumn{7}{|c|}{ Dependent Variable: GDP Growth } & \multicolumn{7}{|c|}{ Dependent Variable: Log of Inflation } \\
\hline & (1) & (2) & (3) & (4) & (5) & (6) & (7) & (8) & (9) & $(10)$ & (11) & $(12)$ & (13) & (14) \\
\hline Fixed & $\begin{array}{l}11.67 \\
(3.99)\end{array}$ & $\begin{array}{c}9.09 \\
(3.40)\end{array}$ & $\begin{array}{c}5.75 \\
(1.90)\end{array}$ & $\begin{array}{c}7.08 \\
(2.15)\end{array}$ & $\begin{array}{c}6.43 \\
(1.84)\end{array}$ & $\begin{array}{l}10.20 \\
(3.27)\end{array}$ & $\begin{array}{c}8.24 \\
(2.70)\end{array}$ & $\begin{array}{c}-2.81 \\
(-6.37)\end{array}$ & $\begin{array}{c}-2.61 \\
(-5.90)\end{array}$ & $\begin{array}{c}-1.93 \\
(-4.22)\end{array}$ & $\begin{array}{c}-1.82 \\
(-3.88)\end{array}$ & $\begin{array}{c}-1.64 \\
(-3.29)\end{array}$ & $\begin{array}{c}-2.45 \\
(-5.32)\end{array}$ & $\begin{array}{c}-2.07 \\
(-4.78)\end{array}$ \\
\hline Fiscal & $\begin{array}{c}0.34 \\
(2.89)\end{array}$ & $\begin{array}{c}0.21 \\
(1.91)\end{array}$ & $\begin{array}{c}0.26 \\
(2.44)\end{array}$ & $\begin{array}{c}0.29 \\
(2.60)\end{array}$ & $\begin{array}{c}0.33 \\
(2.93)\end{array}$ & $\begin{array}{c}0.31 \\
(2.61)\end{array}$ & $\begin{array}{c}0.29 \\
(2.60)\end{array}$ & $\begin{array}{c}-0.07 \\
(-3.98)\end{array}$ & $\begin{array}{c}-0.06 \\
(-3.35)\end{array}$ & $\begin{array}{c}-0.06 \\
(-3.63)\end{array}$ & $\begin{array}{c}-0.06 \\
(-3.77)\end{array}$ & $\begin{array}{c}-0.07 \\
(-4.27)\end{array}$ & $\begin{array}{c}-0.06 \\
(-3.61)\end{array}$ & $\begin{array}{c}-0.06 \\
(-3.77)\end{array}$ \\
\hline Y92 & & $\begin{array}{l}-8.51 \\
(-4.44)\end{array}$ & & & & & & & $\begin{array}{c}0.67 \\
(2.13)\end{array}$ & & & & & \\
\hline CLI & & & $\begin{array}{c}4.99 \\
(4.07)\end{array}$ & & & & & & & $\begin{array}{c}-0.74 \\
(-3.96)\end{array}$ & & & & \\
\hline Liberal & & & & $\begin{array}{l}30.72 \\
(2.70)\end{array}$ & & & & & & & $\begin{array}{c}-6.65 \\
(-4.09)\end{array}$ & & & \\
\hline LIE & & & & & $\begin{array}{l}22.50 \\
(2.54)\end{array}$ & & & & & & & $\begin{array}{c}-5.01 \\
(-3.97)\end{array}$ & & \\
\hline LII & & & & & & $\begin{array}{l}13.70 \\
(1.32)\end{array}$ & & & & & & & $\begin{array}{l}-3.31 \\
(-2.15)\end{array}$ & \\
\hline LIP & & & & & & & $\begin{array}{l}28.78 \\
(2.80)\end{array}$ & & & & & & & $\begin{array}{l}-6.16 \\
(-4.20)\end{array}$ \\
\hline R-squared & 0.62 & 0.70 & 0.69 & 0.66 & 0.65 & 0.63 & 0.66 & 0.74 & 0.76 & 0.79 & 0.79 & 0.79 & 0.76 & 0.79 \\
\hline Adjusted R-squared & 0.49 & 0.59 & 0.58 & 0.53 & 0.52 & 0.49 & 0.53 & 0.65 & 0.67 & 0.71 & 0.71 & 0.71 & 0.67 & 0.72 \\
\hline Likelihood ratio & 67.32 & 78.68 & 57.64 & 53.44 & 53.46 & 57.54 & 60.29 & 79.21 & 81.36 & 61.20 & 59.10 & 62.18 & 53.34 & 77.44 \\
\hline Probability value & 0.000 & 0.000 & 0.000 & 0.001 & 0.001 & 0.000 & 0.000 & 0.000 & 0.000 & 0.000 & 0.000 & 0.000 & 0.001 & 0.000 \\
\hline $\begin{array}{l}\text { Number of } \\
\text { observations }\end{array}$ & 100 & 100 & 100 & 100 & 100 & 100 & 100 & 100 & 100 & 100 & 100 & 100 & 100 & 100 \\
\hline
\end{tabular}

Source: Authors' calculations. 


\section{GROWTH PROSPECTS IN THE LONG-RUN}

The previous section focused on the factors that have affected growth during the transition to a market economy. As the transformation process continues, the forces highlighted in Table 5 are likely to become less important, and will be taken over by the neo classical determinants of growth. This section is devoted to addressing long-term growth prospects in transition economies. Given the short period of time elapsed since the transition process began, any meaningful estimation of long-term growth parameters for transition economies is precluded. Our methodology will therefore consist of drawing upon past cross-country studies of the determinants of growth to make predictions for the transition economies. Assuming that the structural relationships estimated in previous studies are robust, we predict rates of growth for the transition economies, conditional on initial conditions and various control variables (such as investment ratios and government consumption), which are taken to reflect government policies. While admittedly crude-and subject to obvious and some more subtle criticisms - we view this exercise as providing a very rough idea of the long-term growth potential of these economies. ${ }^{16}$

Table 6 presents information on some long-run determinants of growth for those transition economies for which a full data set was available. Data are presented for the latest available year. Thus, population growth rates are for 1993 (source: World Bank); primary and secondary school ratios are mostly for 1993, otherwise one or two years before 1993 (sources: World Bank, and Krajnyak and Zettelmeyer (1996)); gross capital formation is for 1995 (sources: IMF and OECD), exports and government consumption (in percent of GDP) for 1995 (source: IMF); and initial per capita income in U.S. dollars on a purchasing power parity basis is for 1994 (sources: World Bank and IMF).

\footnotetext{
${ }^{16}$ In addition, these rates of growth should be viewed as a long-term average. Based on neoclassical growth theory, one should expect that the initial growth rates would be higher than these averages and then decrease over time as they converge to OECD levels.
} 
Table 6. Factors Affecting Long-term Growth in Transition Economies

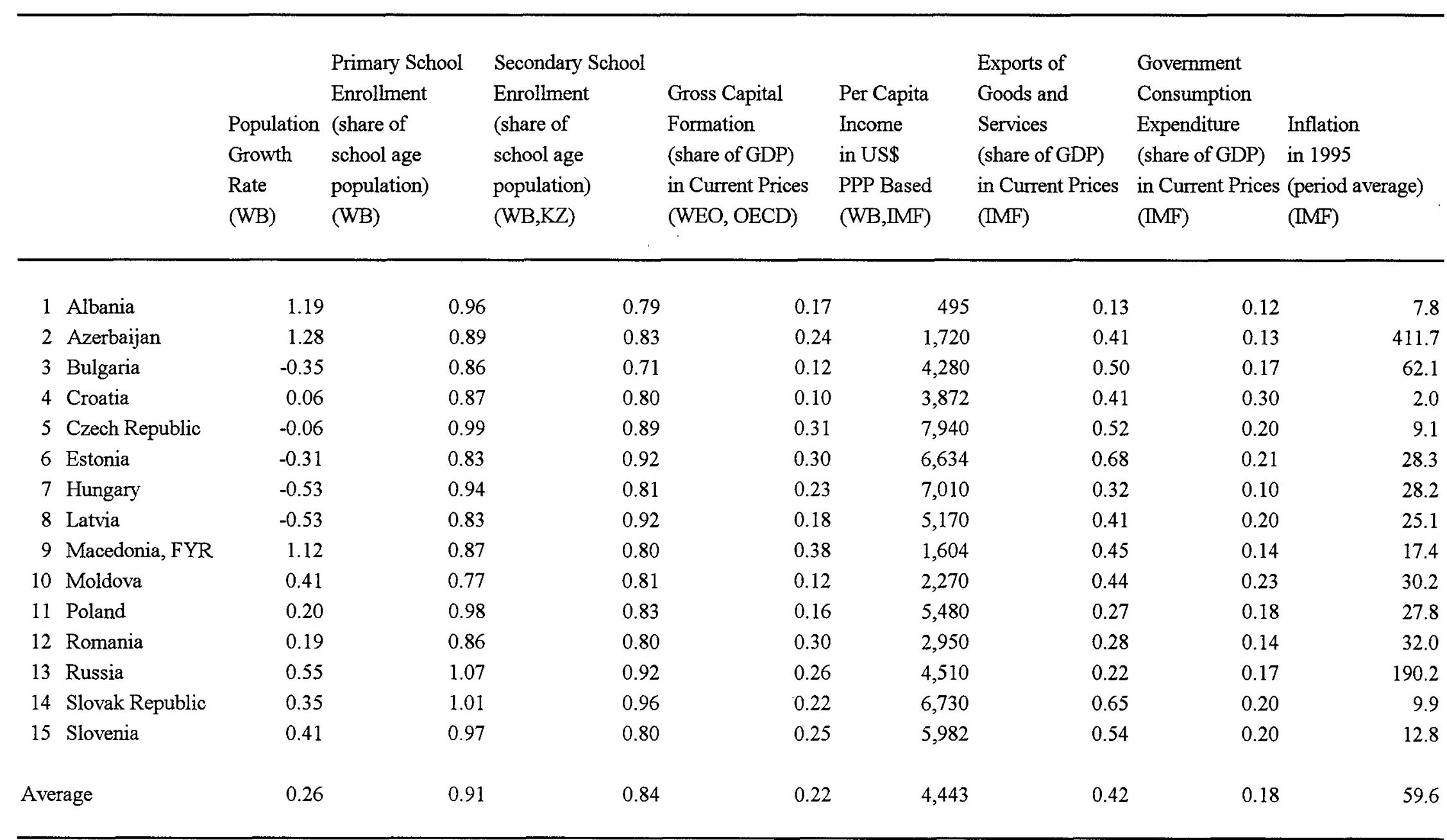

Sources: International Monetary Fund (IMF), The World Bank (WB), Organisation for Economic Co-operation and Development (OECD), and Krajnyak and Zettelmeyer (KZ,1995). 
Given the data available for these countries, we predict future growth prospects using an equation of the form:

$\mathrm{g}(\mathrm{t})=\mathrm{f}\left(\mathrm{Y}_{0}, \mathrm{PS}_{0}, \mathrm{SS}_{0} ; \mathrm{INV}(\mathrm{t}), \mathrm{GOV}(\mathrm{t}), \operatorname{POP}(\mathrm{t})\right)$
$-+++?+$

where $g(t)$ is per capita growth during the time interval $t, Y_{0}$ is the per capita income in the starting year, $\mathrm{PS}_{0}$ is the primary school enrollment rate (in percent of the total primary schoolaged population), $\mathrm{SS}_{0}$ is the secondary school enrollment rate (in percent of the total secondary school-aged population), INV(t) is gross capital formation (in percent of GDP) during the time interval $t, G O V(t)$ is government consumption expenditure (in percent of GDP) during the time interval $t$, and $\mathrm{POP}(\mathrm{t})$ is the growth rate of the population during the time interval $t$.

The predicted signs from neoclassical and endogenous growth models are presented below the explanatory variables in equation (1). Per capita growth, $\mathrm{g}(\mathrm{t})$, is negatively related to $\mathrm{Y}_{0}$ - this follows from the neoclassical convergence hypothesis that, ceteris paribus, poorer countries tend to grow faster than richer ones. The primary and secondary school enrollment ratios represent investment in human capital. Countries investing more in human capital tend to grow faster (see Romer (1990) and Grossman and Helpman (1991)). Higher physical investment ratios also increase the growth rate. There is no consensus in the empirical literature regarding the effects of government consumption on growth (for contrasting results, see Ram (1986) and Levine and Renelt (1992)). The impact on growth should depend on the type of government spending, as well as on the distortions associated with its financing. Some growth models with endogenous population growth predict that per capita income and population growth rates should move inversely because higher population growth rates imply that a larger amount of time is spent in raising children than in other productive activities.

Referring back to the basic data in Table 6, the PPP-based per capita income (in U.S. dollars) varies widely across countries, with Albania at the low end of the spectrum and the Czech Republic at the other extreme. In 1994, all countries were well below the OECD country average of $\$ 18,602$. The average per capita income $(\$ 4,443)$ is also low from a global perspective-by World Bank (1996) standards these are lower-middle income economies. Given the relatively low initial per capita incomes, the convergence hypothesis predicts a relatively faster rate of growth in the future.

The most striking features in Table 6 are the extremely high primary and secondary school enrollment ratios. Other things being equal, these ratios imply a higher growth potential. However, despite the high level of basic education existing in most of the transition 
economies, further human capital investment is required to provide retraining in market-based institutions, build entrepreneurial skills, and ensure technological innovation and adaptation. ${ }^{17}$

The latest available information on gross capital formation indicates that the average in 1994 stood at 22 percent of GDP, and that there was a wide variation across countries. While this average figure is comparable to the one prevailing in the industrial countries during the period 1950-73, it is low compared to the average of 30 percent for the fast growing economies during the period $1985-94 .^{18}$

Government consumption in most countries declined sharply from a level of 50-60 percent of GDP at the start of the transformation process, to an average level of 18 percent in $1995 .^{19}$ While government consumption at the previous rates was not sustainable and must have affected growth negatively, it is becoming increasingly clear that sharp reductions in expenditures on the scale seen in some of the transition economies may be adversely affecting the reform process (see, for example, Haque and Sahay (1996)). Involuntary expenditure compression, sequestration, and a build-up of arrears have often resulted from the sharp revenue declines and the need to reduce budget deficits for various reasons (including stabilization, see Cheasty and Davis (1996)). Indeed, it is likely that growth would be enhanced by more public spending on building market-based institutions, improving the quality of government administration, and setting up a social safety net. ${ }^{20}$

Population growth rates in the transition economies are low, and in many cases negative. As the extensive state support system for dependents, particularly children, is reduced, we would expect a further decline in population growth rates. According to equation (1), this means higher per capita growth. However it is also likely that population growth rates will recover once the economic prospects for individuals in these economies become less uncertain.

${ }^{17}$ Despite consistently high human capital indicators, Easterly and Fischer (1994) show that a leading cause of economic decline in the former Soviet Union was the low elasticity of substitution between capital and labor, which they argue were in part explained by lack of entrepreneurial skills and the slow adaptation to imported technological progress.

${ }^{18}$ This group of countries includes Chile, Hong Kong, Korea (South), Malaysia, Mauritius, Singapore, Taiwan Province of China, and Thailand (based on the IMF's World Economic Outlook database.)

${ }^{19}$ We have to repeat the standard warning on data: data on gross capital formation as well as on government consumption are subject to a wide margin of error, primarily because the demand-based UN system of national income accounting is still at a very rudimentary stage in most of these countries.

${ }^{20}$ Keefer and Knack (1995) present empirical evidence from cross-country growth regressions that point to the positive impact on growth of better institutions. 
Table 7 provides preliminary insights on the growth potential in transition economies by comparing key determinants of growth with past averages for slow and fast-growing countries presented in Levine and Renelt (1992). Again, human capital indicators are extremely favorable and so is the degree of openness of the economies. The inflation rate in 1995 was still quite high (and much higher than the average for both subgroups) but given current stabilization policies, we can expect the recent trend of rapid decline in inflation rates to continue. $^{21}$

To project long-term growth in transition economies, we used the equations estimated by Barro (1991) and Levine and Renelt (1992). ${ }^{22}$ Tables 8, 9, and 10 present our simulation results under alternative specifications. These are:

Barro growth equation:

per capita growth $=0.0302 *-0.0075 * \mathrm{Y}_{1960}+0.025 *$ PRIM

$$
+0.0305 * \text { SEC }-0.119 * \text { GOV }
$$

Levine and Renelt growth equation:

per capita growth $=-0.83-0.35^{*} \mathrm{Y}_{1960}-0.38 \mathrm{POP}$

$$
+3.17 * \mathrm{SEC}+17.5 * \mathrm{INV}
$$

Here $\mathrm{Y}_{1960}$ is the initial level of real per capita income at international prices (expressed in logs in the Barro equation and divided by 1,000 in the Levine-Renelt equation), POP is the growth rate of population, PRIM is the gross primary school enrollment rate, SEC is the gross secondary school enrollment rate, GOV is the share of government consumption expenditure in GDP, and INV is the share of investment in GDP. (The stars next to the estimated coefficients indicate that they are significant at least at the 5 percent level.)

\footnotetext{
${ }^{21}$ See Fischer (1993) for evidence that inflation is negatively associated with growth.

${ }^{22}$ We chose these equations both because they are widely quoted and because it was relatively straightforward to obtain data for the transition economies matching the right-hand side variables in the Barro (1991) and Levine and Renelt (1992) regressions.
} 
Table 7. Selected Transition Economies in a Global Perspective

\begin{tabular}{lccc}
\hline \multicolumn{1}{c}{ Variable } & Fast-growers & Slow-growers & $\begin{array}{c}\text { Transition Economies } \\
\text { in 1995 1/ }\end{array}$ \\
\hline $\begin{array}{l}\text { Primary-school enrollment rate } \\
\text { (in 1960) }\end{array}$ & 0.90 & 0.54 & 0.91 \\
$\begin{array}{l}\text { Secondary-school enrollment rate } \\
\text { (in 1960) }\end{array}$ & 0.30 & 0.10 & 0.84 \\
$\begin{array}{l}\text { Share of investment in GDP } \\
\text { (during 1960-89) }\end{array}$ & 0.23 & 0.17 & 0.22 \\
$\begin{array}{l}\text { Government consumption/GDP } \\
\text { (during 1960-89) }\end{array}$ & 0.16 & 0.12 & 0.18 \\
$\begin{array}{l}\text { Share of exports to GDP } \\
\text { (during 1960-89) }\end{array}$ & & & 0.42 \\
Annual inflation rate & & & \\
(during 1960-89) & 0.32 & 0.23 & 59.6 \\
\hline
\end{tabular}

Sources: Levine and Renelt (1992), and Table 6.

1/ Average for 15 transition economies. 
Table 8. Selected Transition Economies: Forecasting Long-Term Trend Growth (Barro)

\begin{tabular}{|c|c|c|c|c|c|c|c|c|}
\hline & & $\begin{array}{l}\text { Population } \\
\text { Growth } \\
\text { Rate } \\
\text { (WB) }\end{array}$ & $\begin{array}{l}\text { Primary School } \\
\text { Enrollment } \\
\text { (share of } \\
\text { school age } \\
\text { population) } \\
\text { (WB) }\end{array}$ & $\begin{array}{l}\text { Second. School } \\
\text { Enrollment } \\
\text { (share of } \\
\text { school age } \\
\text { population) } \\
\text { (WB,KZ) }\end{array}$ & $\begin{array}{c}\text { Per Capita } \\
\text { Income } \\
\text { in US\$ } \\
\text { PPP } \\
\text { Based } \\
\text { (WB,IMF) }\end{array}$ & $\begin{array}{c}\text { Government } \\
\text { Consumption } \\
\text { Expenditure } \\
\text { (share of GDP) } \\
\text { in Current Prices } \\
\text { (IMF) }\end{array}$ & $\begin{array}{c}\text { Forecasted } \\
\text { Per Capita } \\
\text { Growth } \\
\text { Rate }\end{array}$ & $\begin{array}{c}\text { Forecasted } \\
\text { Growth } \\
\text { Rate }\end{array}$ \\
\hline 1 & Albania & 1.19 & 0.96 & 0.79 & 495 & 0.12 & 6.91 & 8.09 \\
\hline 2 & Azerbaijan & 1.28 & 0.89 & 0.83 & 1720 & 0.13 & 5.77 & 7.05 \\
\hline 3 & Bulgaria & -0.35 & 0.86 & 0.71 & 4280 & 0.17 & 4.28 & 3.93 \\
\hline 4 & Croatia & 0.06 & 0.87 & 0.80 & 3872 & 0.30 & 3.08 & 3.14 \\
\hline 5 & Czech Republic & -0.06 & 0.99 & 0.89 & 7940 & 0.20 & 4.24 & 4.18 \\
\hline 6 & Estonia & -0.31 & 0.83 & 0.92 & 6634 & 0.21 & 3.98 & 3.67 \\
\hline 7 & Hungary & -0.53 & 0.94 & 0.81 & 7010 & 0.10 & 5.15 & 4.62 \\
\hline 8 & Latvia & -0.53 & 0.83 & 0.92 & 5170 & 0.20 & 4.27 & 3.75 \\
\hline 9 & Macedonia, FYR & 1.12 & 0.87 & 0.80 & 1604 & 0.14 & 5.61 & 6.72 \\
\hline 10 & Moldova & 0.41 & 0.77 & 0.81 & 2270 & 0.23 & 4.10 & 4.51 \\
\hline 11 & Poland & 0.20 & 0.98 & 0.83 & 5480 & 0.18 & 4.59 & 4.79 \\
\hline 12 & Romania & 0.19 & 0.86 & 0.80 & 2950 & 0.14 & 5.16 & 5.35 \\
\hline 13 & Russia & 0.55 & 1.07 & 0.92 & 4510 & 0.17 & 5.32 & 5.87 \\
\hline 14 & Slovak Republic & 0.35 & 1.01 & 0.96 & 6730 & 0.20 & 4.66 & 5.00 \\
\hline 15 & Slovenia & 0.41 & 0.97 & 0.80 & 5982 & 0.20 & 4.16 & 4.57 \\
\hline & Averages & 0.26 & 0.91 & 0.839 & 4443 & 0.18 & 4.75 & 5.02 \\
\hline
\end{tabular}

Sources: International Monetary Fund (IMF), The World Bank (WB), Organisation for Economic Co-operation and Development (OECD), and Krajnyak and Zettelmeyer (KZ,1996). 
Table 9. Selected Transition Economies: Forecasting Long-Term Trend Growth (Levine-Renelt)

\begin{tabular}{|c|c|c|c|c|c|c|c|}
\hline & & $\begin{array}{l}\text { Population } \\
\text { Growth } \\
\text { Rate } \\
\text { (WB) }\end{array}$ & $\begin{array}{l}\text { Secondary School } \\
\text { Enrollment } \\
\text { (share of } \\
\text { school age } \\
\text { population) } \\
\text { (WB,KZ) }\end{array}$ & $\begin{array}{c}\text { Gross } \\
\text { Capital Formation } \\
\text { (share of GDP) } \\
\text { in Current Prices } \\
\text { (OECD, WEO) }\end{array}$ & $\begin{array}{l}\text { Per Capita } \\
\text { Income } \\
\text { in US\$ } \\
\text { PPP Based } \\
\text { (WB,IMF) }\end{array}$ & $\begin{array}{c}\text { Forecasted } \\
\text { Per Capita } \\
\text { Growth } \\
\text { Rate }\end{array}$ & $\begin{array}{c}\text { Forecasted } \\
\text { Growth } \\
\text { Rate }\end{array}$ \\
\hline 1 & Albania & 1.19 & 0.79 & 0.17 & 495 & 4.08 & 5.27 \\
\hline & Azerbaijan & 1.28 & 0.83 & 0.24 & 1,720 & 4.83 & 6.10 \\
\hline 3 & Bulgaria & -0.35 & 0.71 & 0.12 & 4,280 & 2.16 & 1.80 \\
\hline 4 & Croatia & 0.06 & 0.80 & 0.10 & 3,872 & 1.99 & 2.06 \\
\hline 5 & Czech Republic & -0.06 & 0.89 & 0.31 & 7,940 & 4.66 & 4.60 \\
\hline & Estonia & -0.31 & 0.92 & 0.30 & 6,634 & 5.18 & 4.86 \\
\hline 7 & Hungary & -0.53 & 0.81 & 0.23 & 7,010 & 3.51 & 2.98 \\
\hline & Latvia & -0.53 & 0.92 & 0.18 & 5,170 & 3.63 & 3.10 \\
\hline & Macedonia, FYR & 1.12 & 0.80 & 0.38 & 1,604 & 7.28 & 8.40 \\
\hline 10 & Moldova & 0.41 & 0.81 & 0.12 & 2,270 & 2.94 & 3.35 \\
\hline & Poland & 0.20 & 0.83 & 0.16 & 5,480 & 2.59 & 2.79 \\
\hline 12 & Romania & 0.19 & 0.80 & 0.30 & 2,950 & 5.80 & 5.99 \\
\hline & Russia & 0.55 & 0.92 & 0.26 & 4,510 & 4.83 & 5.38 \\
\hline & Slovak Republic & 0.35 & 0.96 & 0.22 & 6,730 & 3.63 & 3.98 \\
\hline \multirow{2}{*}{\multicolumn{2}{|c|}{15 Slovenia }} & 0.41 & 0.80 & 0.25 & 5,982 & 3.78 & 4.19 \\
\hline & & 0.26 & 0.84 & 0.22 & 4,443 & 4.06 & 4.32 \\
\hline
\end{tabular}

Sources: International Monetary Fund (IMF), The World Bank (WB), Organisation for Economic Co-operation and Development (OECD), and Krajnyak and Zettelmeyer (KZ,1996). 
Table 10. Selected Transition Economies: Forecasting GDP Convergence to OECD Countries

\begin{tabular}{|c|c|c|c|c|c|c|c|c|c|}
\hline & \multirow[b]{3}{*}{$\begin{array}{c}\text { Per Capita } \\
\text { Income } \\
\text { in US\$ } \\
\text { (PPP Based) } \\
\text { (WB, IMF:1994) }\end{array}$} & \multicolumn{4}{|c|}{ Barro } & \multicolumn{4}{|c|}{ Levine-Renelt } \\
\hline & & \multicolumn{2}{|l|}{$\begin{array}{c}\text { At Current } \\
\text { Government } \\
\text { onsumption Rates } \\
\end{array}$} & \multicolumn{2}{|c|}{$\begin{array}{c}\text { Government Consumption } \\
=10 \text { Percent } \\
\text { (in Percent of GDP) }\end{array}$} & \multicolumn{2}{|l|}{$\begin{array}{c}\text { At Current } \\
\text { Investment Rates }\end{array}$} & \multicolumn{2}{|l|}{$\begin{array}{c}\text { Investment } \\
=30 \text { Percent } \\
\text { (In Percent of GDP) }\end{array}$} \\
\hline & & $\begin{array}{c}\text { Forecasted } \\
\text { Per Capita } \\
\text { Growth }\end{array}$ & $\begin{array}{c}\text { Number of } \\
\text { Years to } \\
\text { Reach Current } \\
\text { OECD Levels }\end{array}$ & $\begin{array}{l}\text { Forecasted } \\
\text { Per Capita } \\
\text { Growth }\end{array}$ & $\begin{array}{c}\text { Number of } \\
\text { Years to } \\
\text { Reach Current } \\
\text { OECD Levels }\end{array}$ & $\begin{array}{l}\text { Forecasted } \\
\text { Per Capita } \\
\text { Growth }\end{array}$ & $\begin{array}{c}\text { Number of } \\
\text { Years to } \\
\text { Reach Current } \\
\text { OECD Levels }\end{array}$ & $\begin{array}{l}\text { Forecasted } \\
\text { Per Capita } \\
\text { Growth }\end{array}$ & $\begin{array}{l}\text { Number of } \\
\text { Years to } \\
\text { Reach Current } \\
\text { OECD Levels }\end{array}$ \\
\hline 1 Albania & 495 & 6.91 & 54 & 7.17 & 52 & 4.08 & 91 & 6.30 & 59 \\
\hline 2 Azerbaijan & 1,720 & 5.77 & 42 & 6.18 & 40 & 4.83 & 51 & 5.96 & 41 \\
\hline 3 Bulgaria & 4,280 & 4.28 & 35 & 5.06 & 30 & 2.16 & 69 & 5.31 & 28 \\
\hline 4 Croatia & 3,872 & 3.08 & 52 & 5.43 & 30 & 1.99 & 80 & 5.58 & 29 \\
\hline 5 Czech Republic & 7,940 & 4.24 & 20 & 5.47 & 16 & 4.66 & 19 & 4.48 & 19 \\
\hline 6 Estonia & 6,634 & 3.98 & 26 & 5.29 & 20 & 5.18 & 20 & 5.13 & 21 \\
\hline 7 Hungary & 7,010 & 5.15 & 19 & 5.19 & 19 & 3.51 & 28 & 4.74 & 21 \\
\hline 8 Latvia & 5,170 & 4.27 & 31 & 5.48 & 24 & 3.63 & 36 & 5.73 & 23 \\
\hline 9 Macedonia, FYR & 1,604 & 5.61 & 45 & 6.09 & 41 & 7.28 & 35 & 5.97 & 42 \\
\hline 10 Moldova & 2,270 & 4.10 & 52 & 5.61 & 39 & 2.94 & 73 & 6.04 & 36 \\
\hline 11 Poland & 5,480 & 4.59 & 27 & 5.54 & 23 & 2.59 & 48 & 5.06 & 25 \\
\hline 12 Romania & 2,950 & 5.16 & 37 & 5.61 & 34 & 5.80 & 33 & 5.85 & 32 \\
\hline 13 Russia & 4,510 & 5.32 & 27 & 6.18 & 24 & 4.83 & 30 & 5.55 & 26 \\
\hline 14 Slovak Republic & 6,730 & 4.66 & 22 & 5.85 & 18 & 3.63 & 29 & 4.98 & 21 \\
\hline 15 Slovenia & 5,982 & 4.16 & 28 & 5.35 & 22 & 3.78 & 31 & 4.71 & 25 \\
\hline Average for transition & 4,443 & 4.75 & 35 & 5.70 & 29 & 4.06 & 45 & 5.43 & 30 \\
\hline OECD average (1994) & 18,602 & n.a & & & & n.a & & & \\
\hline
\end{tabular}


The average per capita growth rates forecasted by Barro and Levine-Renelt's equations are fairly close - between 4 and 5 percent per annum (Tables 8 and 9). The more optimistic scenario for most countries, not surprisingly, is obtained by using the Barro equation (Table 8), which gives a relatively high weight to the human capital variables. The projected average per capita growth rate is 4.75 percent, with all countries within the range of 3-7 percent. In the simulation based on the Levine and Renelt equation (Table 9), the per capita growth rate falls to about 4 percent. The relative per capita growth rates of the countries also change: for example, Albania's per capita growth rate declines from 7 percent to about 4 percent, while Estonia's ranking rises sharply. The main force that brings about this difference is the inclusion of investment in Levine and Renelt, but not in Barro. ${ }^{23}$

Based on initial per capita income and the projected growth rates, Table 10 indicates the number of years it would take for each of these economies to reach the current average per capita income of the OECD. Given initial conditions and current economic policies, it would take on average 35 years according to the Barro regression and 45 years according to the Levine and Renelt equation. The best-placed countries appear to be the Czech Republic and Estonia, which would converge in around 20-25 years according to both regressions.

We set out policy implications in Table 10, by asking how the long-term average per capita growth would be affected if investments rates were raised and government consumption reduced in the future. The results suggest that changes in investment ratios would have significant implications for long-term growth. For instance, under the Levine-Renelt specification, the numbers of years to reach current OECD levels declines from 45 years to 30 years as investment rates rise by 8 percentage points (from 22 percent to 30 percent), on average. The effects of reducing government expenditure by 8 percentage points (from 18 percent to 10 percent in the Barro equation) are less noticeable, with the numbers of years to reach OECD levels declining by only 6 years.

This simple exercise thus suggests that the key to rapid growth in the transition economies is adopting policies that promote investment. It should be noted, however, that particular attention should be given to the quality of investment. While many of the transition economies have traditionally had high investment ratios, the efficiency of the capital stock has typically been low. Hence, policies should focus not only on increasing the level of investment, but also on improving its efficiency.

Finally, it should be stressed that the projections have abstracted from some potentially very important external, political, and institutional factors. While such factors are hard to assess

\footnotetext{
${ }^{23}$ It should be noted that the projections are very sensitive to current policies (in particular investment ratios). Since investment ratios may differ quite a bit from year to year, the scenario below, which assumes a uniform rate of investment of 30 percent of GDP, may convey a better, if optimistic, picture.
} 
quantitatively (even in the existing growth literature), they are likely to have an important influence on the growth process.

\section{CONCLUDING REMARKS}

This paper has analyzed the growth and inflation performance of the transition economies and given a rough idea of their long-term growth potential. While it is clear that the costs of the transition have been high (even adjusting for data problems), the goods news is that the worst appears to be over, and most transition economies in our sample had begun to grow by 1996. While admittedly crude, projections based on standard growth regressions suggest that it will take around 20 years for the faster reformers to reach current OECD per capita income levels.

Many of the transition economies have moved rapidly on several of the necessary fronts, particularly in liberalizing the price, foreign exchange and trade regimes. In most economies, privatization of state enterprises is still far from complete and the banking system is under severe strain. Under these conditions, benefits from properly directed government spending on reforms and from foreign direct investment in enhancing human and physical capital are potentially large. While not all transition economies are equally well placed, the starting conditions are favorable in most countries. Policies will make all the difference. 


\section{REFERENCES}

Aslund, Anders, Peter Boone, and Simon Johnson, 1996, "How to Stabilize: Lessons from Post-Communist Countries," prepared for the Brookings Panel on Economic Activity, March 28-29.

Barro, Robert J., 1991, "Economic Growth in a Cross-Section of Countries," Quarterly Journal of Economics, Vol. 106, pp. 407-43.

Barro, Robert J., and Jong-Wha Lee, 1993, "International Comparisons for Educational Attainment," Journal of Monetary Economics, Vol. 32, pp. 363-394.

Cheasty, Adrienne, and Jeffrey Davis, 1996, "Fiscal Transition in Countries of the Former Soviet Union: An Interim Assessment," unpublished (Washington: International Monetary Fund).

De Melo, Martha, Cevdet Denizer, and Alan Gelb, 1996, "From Plan to Market: Patterns of Transition" unpublished (Washington: The World Bank).

Easterly, William, "When is Stabilization Expansionary?," 1995, unpublished, forthcoming in Economic Policy (Washington: The World Bank).

Easterly, William, and Stanley Fischer, March 1994, "The Soviet Economic Decline: Historical and Republican Data," unpublished (Washington: The World Bank).

European Bank for Reconstruction and Development, October 1994, Transition Report (London: EBRD).

European Bank for Reconstruction and Development, April 1995, Transition Report Update, (London: EBRD).

Fischer, Stanley, "The Role of Macroeconomic Factors in Growth," 1993, Journal of Monetary Economics, Vol. 32, pp. 485-512.

Fischer, Stanley, Ratna Sahay, and Carlos A. Végh, 1996a, "Stabilization and Growth in Transition Economies: The Early Experience", Journal of Economic Perspectives, Vol. 10 (Spring), pp. 45-66.

Fischer, Stanley, Ratna Sahay, and Carlos A. Végh, 1996b, "Economies in Transition: The Beginnings of Growth", American Economic Review, Papers and Proceedings, Vol. 86, pp. 229-233.

Grossman, Gene M., and Elhanan Helpman, 1991, Innovation and Growth in the Global Economy (Cambridge, Massachusetts: MIT Press). 
Haque, Nadeem Ul, and Ratna Sahay, 1996, "Do Government Wage Cuts Close Budget Deficits?-A Conceptual Framework for Developing Countries and Transition Economies," IMF Working Paper 96/19, forthcoming in IMF Staff Papers (Washington: International Monetary Fund).

Hansson, Ardo, and Jeffrey Sachs, 1994, "Monetary Institutions and Credible Stabilization: A Comparison of Experience in the Baltics," unpublished (Cambridge, Massachusetts: Harvard University).

Kaufmann, Daniel and Aleksander Kaliberda, 1995, "Integrating the Unofficial Economy into the Dynamics of Post-Socialist Economies: A Framework of Analysis and Evidence," unpublished (Kyiv: The World Bank Kyiv office).

Krajnyak, Kornelia and Jeromin Zettelmeyer, 1996, "Competitiveness in Transition Economies, unpublished (Washington: International Monetary Fund).

Levine, Ross and David Renelt, 1992, "A Sensitivity Analysis of Cross-Country Growth Regressions", American Economic Review, Vol. 82, pp. 942-63.

Organisation for Economic Co-operation and Development, January 1996, Short-term Economic Indicators: Transition Economies, Centre for Co-operation with the Economies in Transition.

Ram, Rati, "Wagner's Hypothesis in Time Series and Cross-Section Perspectives: Evidence from 'Real' Data for 155 Countries," 1986, Review of Economics and Statistics, pp. 194-204.

Rebelo, Sergio, and Carlos A. Végh, 1995, "Real Effects of Exchange Rate-Based Stabilization: An Analysis of Competing Theories," NBER Macroeconomics Annual, pp. $125-174$.

Romer, Paul M., 1990, "Endogenous Technological Change," Journal of Political Economy, Vol. 98, pp. S71-S102.

Sachs, Jeffrey, May 1996, "It Could Have Been So Much Better", Moscow Times.

Sahay, Ratna, and Carlos A. Végh, 1996, "Inflation and Stabilization in Transition Economies: An Analytical Interpretation of the Evidence," Journal of Policy Reform, Vol. 1, pp. 75-108.

The World Bank, 1996, The World Bank Atlas. 